\title{
WestVirginiaUniversity
}

THE RESEARCH REPOSITORY @ WVU

Graduate Theses, Dissertations, and Problem Reports

2017

\section{Evaluation of Energy Efficiency Performance of Heated Windows}

Hari Swarup Jammulamadaka

Follow this and additional works at: https://researchrepository.wvu.edu/etd

\section{Recommended Citation}

Jammulamadaka, Hari Swarup, "Evaluation of Energy Efficiency Performance of Heated Windows" (2017). Graduate Theses, Dissertations, and Problem Reports. 5879.

https://researchrepository.wvu.edu/etd/5879

This Thesis is protected by copyright and/or related rights. It has been brought to you by the The Research Repository @ WVU with permission from the rights-holder(s). You are free to use this Thesis in any way that is permitted by the copyright and related rights legislation that applies to your use. For other uses you must obtain permission from the rights-holder(s) directly, unless additional rights are indicated by a Creative Commons license in the record and/ or on the work itself. This Thesis has been accepted for inclusion in WVU Graduate Theses, Dissertations, and Problem Reports collection by an authorized administrator of The Research Repository @ WVU. For more information, please contact researchrepository@mail.wvu.edu. 


\title{
Evaluation of Energy Efficiency Performance of Heated Windows
}

\author{
Hari Swarup Jammulamadaka
}

Thesis submitted

to the Benjamin M. Statler College of Engineering and Mineral Resources at West Virginia University

in partial fulfillment of the requirements for the degree of

Master of Science in

Industrial Engineering

$$
\begin{gathered}
\text { Bhaskaran Gopalakrishnan, Ph.D., PE } \\
\text { Kenneth Means, Ph.D., PE } \\
\text { Kennth Currie, Ph.D., PE } \\
\text { Edward Crowe, Ph.D., PE }
\end{gathered}
$$

Department of Industrial and Management Systems Engineering

$$
\begin{gathered}
\text { Morgantown, West Virginia } \\
2017
\end{gathered}
$$

Keywords: Heated Windows, Perimeter Heating, Window Efficiency Copyright 2017 Hari Swarup Jammulamadaka 


\title{
Abstract \\ Evaluation of Energy Efficiency Performance of Heated Windows
}

\author{
Hari Swarup Jammulamadaka
}

The study about the evaluation of the performance of the heated windows was funded by the WVU Research Office as a technical assistance award at the 2014 TransTech Energy Business Development Conference to the Green Heated Glass company/project owned by Frank Dlubak. The award supports a WVU researcher to conduct a project important for commercialization. This project was awarded to the WVU Industrial Assessment Center in 2015.

The current study attempted to evaluate the performance of the heated windows by developing an experimental setup to test the window at various temperatures by varying the power input to the window. The heated double pane window was installed in an insulated box. A temperature gradient was developed across the window by cooling one side of the window using gel based ice packs. The other face of the window was heated by passing power at different wattages through the window. The temperature of the inside and outside panes, current and voltage input, room and box temperature were recorded, and used to calculate the apparent $\mathrm{R}$-value of the window when not being heated vs when being heated.

It has been concluded from the study that the heated double pane window is more effective in reducing heat losses by as much as $50 \%$ than a non-heated double pane window, if the window temperature is maintained close to the room temperature. If the temperature of the window is much higher than the room temperature, the losses through the window appear to increase beyond that of a non-heated counterpart. The issues encountered during the current round of experiments are noted, and recommendations provided for future studies. 


\section{Acknowledgement}

I would like to thank my committee chair, Dr. Bhaskaran Gopalakrishnan, and Dr.

Kenneth Means for their continued support and guidance throughout the course of the Master Program. I also wish to thank Dr. Kenneth Currie and Dr. Ed Crowe for their advice and support through the course of graduate school.

l'd like to thank Dr. Carl Irwin and TransTech for giving me an opportunity to work on this interesting and sparsely explored project. I would also like to thank Frank Dlubak, owner of Green Heated Glass company, who supplied the Industrial Assessment Center with sampled of heated glass that were tested in this study.

Above all, I wish to thank my parents for standing by me through the good times and the bad, and always being there. I cannot forget to acknowledge my friends and peers at IAC who made my time in graduate school worthwhile. 


\section{Table of Contents}

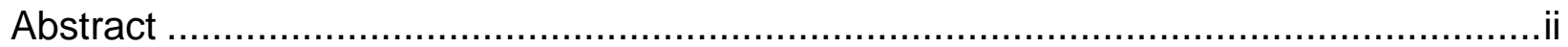

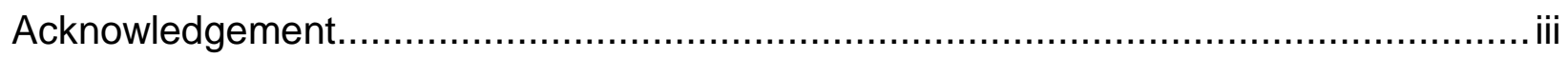

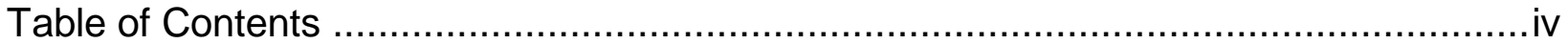

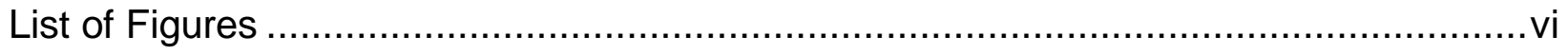

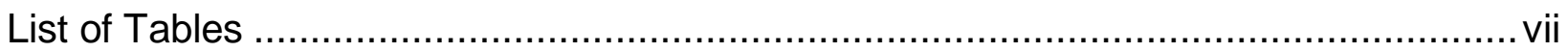

List of Symbols, Abbreviations, or Nomenclature .................................................... viii

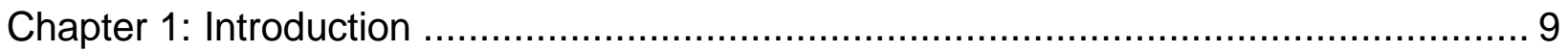

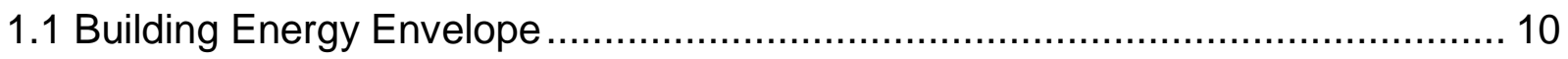

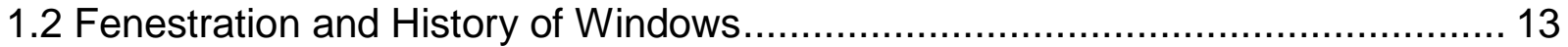

1.3 Window Technologies to Improve Window Energy Performance ....................... 15

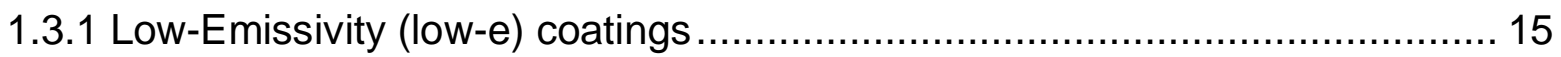

1.3.2 Spectrally Selective Coatings or Tints...................................................... 16

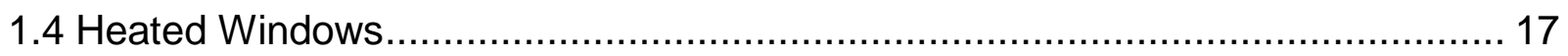

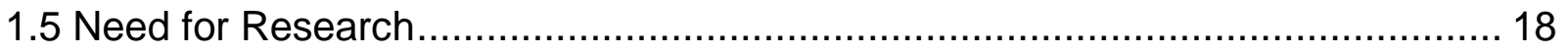

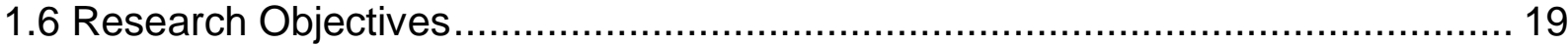

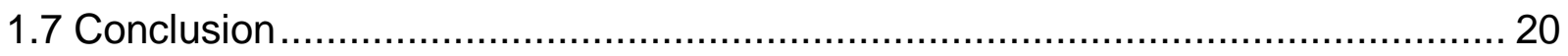

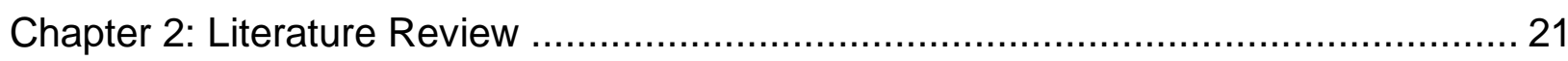

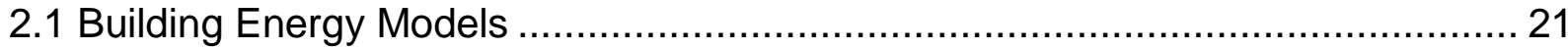

2.2 Fenestration and Energy Efficient Window Technologies............................... 21

2.3 Floor and Perimeter Heating ...................................................................... 23

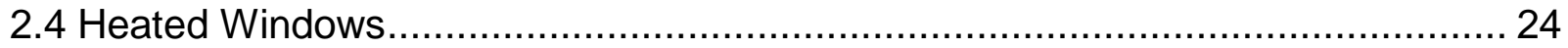

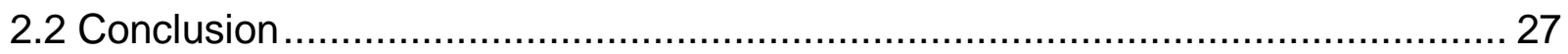

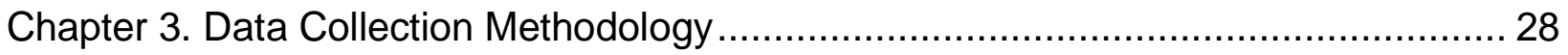

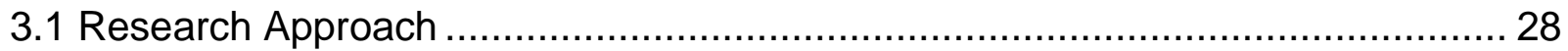

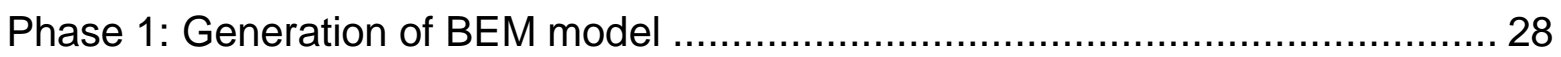

Phase 2: Development of heat transfer model for testing the heated window

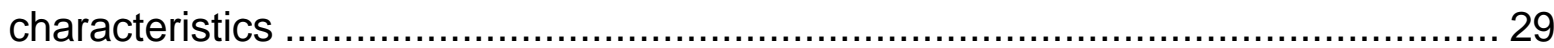

Phase 3: Development of Experimental model and testing of the heated window characteristics 
Phase 4: Data collection and analysis for heat loss through the experimental setup, with, and without heating the glass window. 31

Phase 5: Data collection from a building with heated glass windows during winter.31 3.2 Description of Experimental Setup ................................................................. 32

3.3 Data Collection Methodology ..................................................................... 36

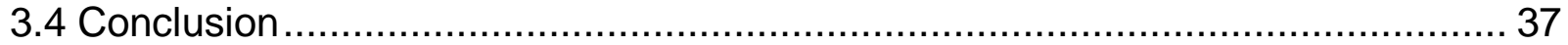

Chapter 4. Results, Discussion, Conclusion, and Future Work ................................ 39

4.1 Window Heat Loss Calculation ................................................................... 40

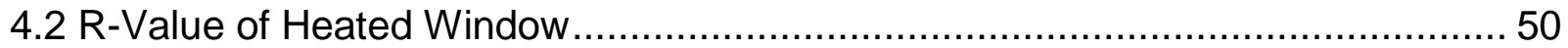

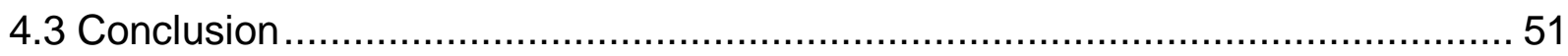

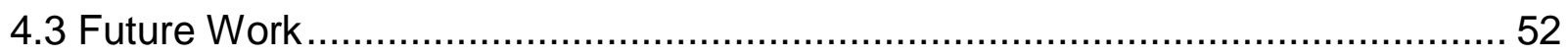

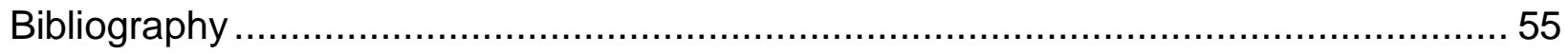

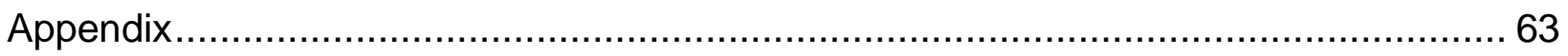




\section{List of Figures}

Figure 1: Heat Loss through different parts of a house .......................................... 11

Figure 2: Factors effecting window performance .................................................. 15

Figure 3: Schematic diagram of a heated window[22] ......................................... 17

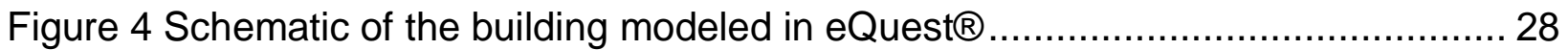

Figure 5 Screenshot of Heat Transfer Model..................................................... 30

Figure 6 Building Schematic where temperature data was collected........................... 32

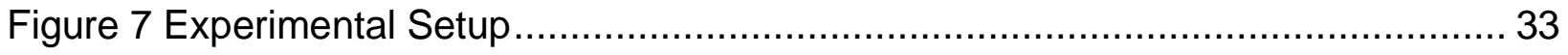

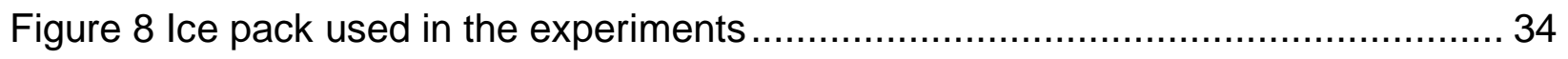

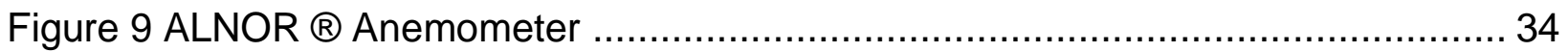

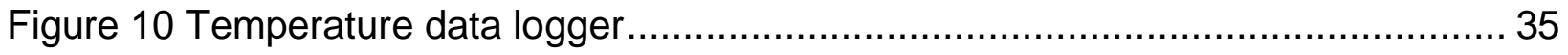

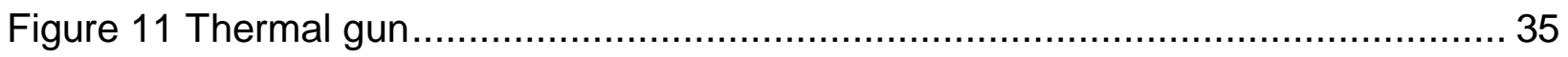

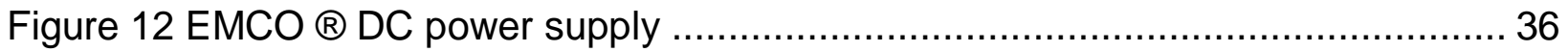

Figure 13 Schematic Diagram of the Experimental Setup …..................................... 40

Figure 14 Error in heat output calculated vs power input.......................................... 44

Figure 15 Comparison of heat loss for heated vs unheated window.......................... 46

Figure 16 Relationship between window temperature and heat loss .......................... 47 


\section{List of Tables}

Table 1: List of major improvements in windows to improve energy efficiency [20], [21]

Table 2 Properties of the window used in the study ............................................ 41

Table 3 Velocity profile across the face of the window for various power inputs........... 41

Table 4 Heat Transfer Properties of air[53] ......................................................... 42

Table 5 Heat loss through the unheated double pane window ................................. 42

Table 6 Heat loss through the heated double pane window ..................................... 42

Table 7 Power input and the respective window temp for different experiments........... 45

Table 8 Heat loss through the heated double pane window at higher heat input .......... 47

Table 9 Cost of Electricity and Natural Gas for Residential Customer in Morgantown,

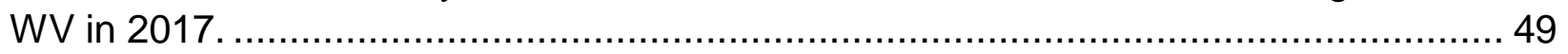

Table 10 Cost savings by installing a heated window............................................... 50 


\section{List of Symbols, Abbreviations, or Nomenclature}

Tamb Ambient Temperature / Temperature of the room

$T_{\text {box }}$ Temperature inside the box, on the surface of the box

$\mathrm{T}_{\text {in }}$ Temperature of the side of the window facing the box

Tout Temperature of the side of the window facing the room

h Convection coefficient of air

kglass Coefficient of thermal conductivity for glass

$\Delta \mathrm{X} \quad$ Thickness of Glass

A Area of the window face

I Current input to the window

V Voltage supplied to the window

$\mathrm{V}_{\mathrm{ii}} \quad$ velocity of air inside the box at location $\mathrm{i}, \mathrm{i}$

Q Heat loss from the window 


\section{Chapter 1: Introduction}

US total energy consumption has remained more or less constant at around 100 quadrillion BTUs since 2000, varying between 94 quadrillion Btu to 101 quadrillion Btu [1]. Of the total energy consumption, $37 \%$ of the energy is consumed by residential and the commercial buildings [2]. Of this, $42 \%$ of the energy is utilized for space heating [3].The United States Department of Energy (DOE) estimates that the windows can account for 10-25 percent of the energy loss through homes [4], which equates to an annual loss of $\$ 35$ Billion every year [5].

The primary reason for the high degree of heat loss/gain through windows is due to their high thermal conductivity in comparison to the walls. Infiltration through the gaps within the windows is also a major contributor to heat loss/gain through windows. Windows which are constructed out of aluminum can also loose or gain heat unless the metal surfaces are insulated.

At present, half of all the energy used for space heating in the US residential sector comes from Natural Gas. The usage patterns vary vastly based on the region of the country. Electricity, however, dominates in the south. The efficiencies and the $\mathrm{CO}_{2}$ emissions vary based on the type of system used. The average $\mathrm{CO}_{2}$ emissions by US has been over 5.33 million Kilo Tons in 2014. Concerns over global climate change due to greenhouse gas emissions, especially $\mathrm{CO}_{2}$, has led to stringent emission norms nationwide, most recently the Clean Power Act, leading to a rise in the utility prices due to the need to upgrade the electric power utilities, rising from 10.40 cents per kwh in 2006 to 12.67 cents

per kWh in 2015 for the residential sector [6]. This has necessitated the need to explore 
various measures by building owners to reduce their utility costs, while investing into upgrades which have a reasonably short payback.

Residential and Commercial heating fuel prices have vastly varied over the past 15 years. While Natural Gas prices have shown a downward trend since the inception of horizontal drilling and fracking in the Marcellus and Utica Shale [7], Electricity prices have gone up steadily. This is primarily due to the increased investment in the transmission and distribution infrastructure [8]. Increased electricity prices and varying natural gas prices make a strong case for further study into reducing the building energy consumption, especially space heating which accounts for almost $40 \%$ of the total energy consumption by the residential sector [3].

\subsection{Building Energy Envelope}

Heat loss through a building depends on a variety of factors. Broadly, the area of the walls and ceiling, insulation material used, area of the windows, and gaps or vents in the house, affect the building energy envelope. The Center for Climate and Energy Solutions [9] defined building envelope as an interface that acts like a thermal barrier between the interior of the building and the outdoor environment, including the walls, roof, and foundation. The building envelope regulates the interior temperatures and helps determine the amount of energy required to maintain thermal comfort. A quick way to detect the heat loss through a building is by taking a thermal image of the building.

The generally accepted percentages of heat loss through a house are shown in Figure 1. Various advancements have been made in the field of energy efficiency of buildings, 
varying from changes like converting to energy efficient lighting, higher insulation in buildings, installation of double and triple pane windows with low-e-coating and lowpressure argon gas filling, to better construction practices. Apart from this, building and appliance codes like Energy Star, LEED, and various other policy measures have led to an overall increase in the energy efficiency in United States, while there is still more opportunities for improvement [10].

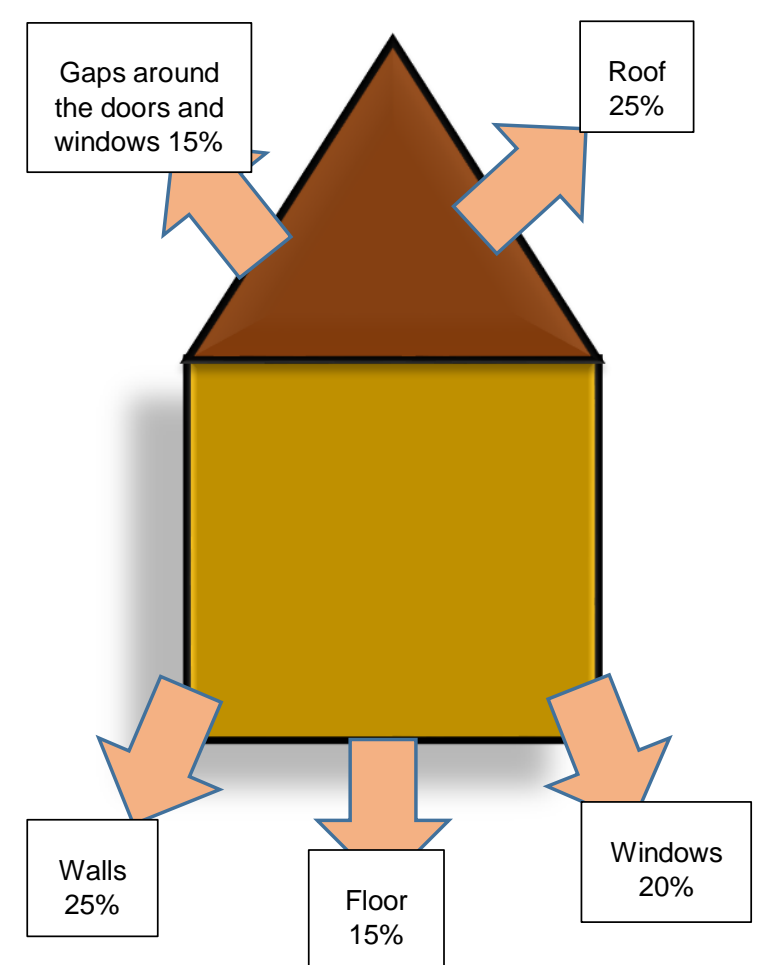

Figure 1: Heat Loss through different parts of a house

Typical energy efficiency designs focus on three aspects: (i) improving building design through active and passive systems, eg. Installing better insulation in the building to reduce heat loss, or reduce cooling load; (ii) improving system/appliance performance, eg. Installing more efficient lighting, or HVAC system; (iii) implementing better control 
strategies to reduce the absolute usage of the appliances to only when they are needed, eg. Programmable thermostats, building management systems, occupancy sensors.

Another important factor defining efficient performance of a heating system is thermal comfort. Thermal Comfort is a subjective assessment by a person expressing their satisfaction with their local thermal environment [11]. The part of a building adjacent to a building envelope tends to be more influenced by the ambient conditions. Thus, if a person sits adjacent to a window during winter time, he would feel colder, since the rate of heat loss from a window is higher. This would influence the individual to increase the set point temperature on the thermostat to feel warmer. Past studies have focused on defining heating the perimeter of a building as a source of improving the thermal comfort inside the building while mostly focusing on heating walls or ceilings [12]-[14]. One such study [15] simulated the energy consumption for various perimeter heating system arrangements and found that energy consumption, while slightly higher in systems where radiant heaters are placed close to the windows, lead to a more uniform temperature distribution and better overall comfort conditions compared to when the radiators are away from the windows. So, the question arises if heating windows themselves would lead to reduction in radiative heat loss during winter time as long as the surface of the window facing the room is warmer and closer to inside temperature and the one facing outside is colder, and closer to ambient temperature.

The idea of floor and perimeter heating for improving building envelope has been picking up in Europe in recent times. More than $50 \%$ of the new buildings in Europe are employing floor heating systems [16]. Some manufacturers claiming that heated double-pane 
windows would lead to much lower effective U-values of the window, saving energy overall.

This study explores whether heating windows would actually reduce the overall heating costs of a building.

\subsection{Fenestration and History of Windows}

Fenestration refers to the arrangement, proportioning, and design of windows and doors in a building. Prior to 1900, windows in US predominantly had wooden frames and metallic frames for institutional buildings. As steel rolling became more popular around 1900, steel frame windows got more popular. After World War 2, aluminum extrusion process was perfected, and aluminum windows began to gain popularity.

According to the US Energy Information Administration, windows in residential setting account for $10-25 \%$ of the exterior wall space. It is estimated that up to $20 \%$ of the heating energy can be saved with more efficient windows in areas with over 5,500 heating degree days a year [17]. Windows also account for $22 \%$ of the heat loss and $32 \%$ of cooling load due to solar heat gain [17]. Therefore, a focus on improving the performance of the windows would lead to significant energy savings. This is also receiving a greater push from the US Department of Energy (DOE) Emerging Technologies 2020 (ET 2020) program, that expects the average Window R-Values to increase from R-5.9/in to R-10/in and the average window costs reduced from $\$ 63 / \mathrm{ft}^{2}$ to $\$ 10 / \mathrm{ft}^{2}[18]$.

The importance that is given to the performance of windows during building design is a recent trait picked up by the industry. Until 1973, heat loss through windows was 
considered to be unavoidable, so HVAC systems were designed to address these losses and meet the building energy loads. After the oil crisis of 1973, there were two reactions towards the realization that windows contributed to $5 \%$ percent of the total energy use in US. (i) Design buildings with smaller windows and board up the windows of existing buildings. (ii) Explore opportunities of improving window performance so they may be employed in the future [19]

To address these issues, various governmental, and non-governmental organizations like the National Fenestration Rating Council and the Industrial Assessment Center, to name a few, were formed. Design methodologies like South-Facing houses, and growing deciduous trees close to the house to provide shade during summer months, while shedding leaves in the winter months to provide light, were promoted more.

Heat gain or heat loss through windows may happen through the conduction, convection, radiation, and infiltration phenomenon. The performance of a window may be defined in terms of rate of heat loss through the window through conduction, convection, and radiation. The term, $U$-value, is used to define this. Higher the $U$-value, greater the heat loss through the window. Therefore, controlling the five factors noted earlier becomes even more important.

Typically, five factors, as shown in Figure 2, effect performance of a window: frame material, spacer material, number of panes, gas between panes, and glazing emissivity. Several improvements in the design of windows have taken place over the years. Table 1 summarizes all these improvements. 


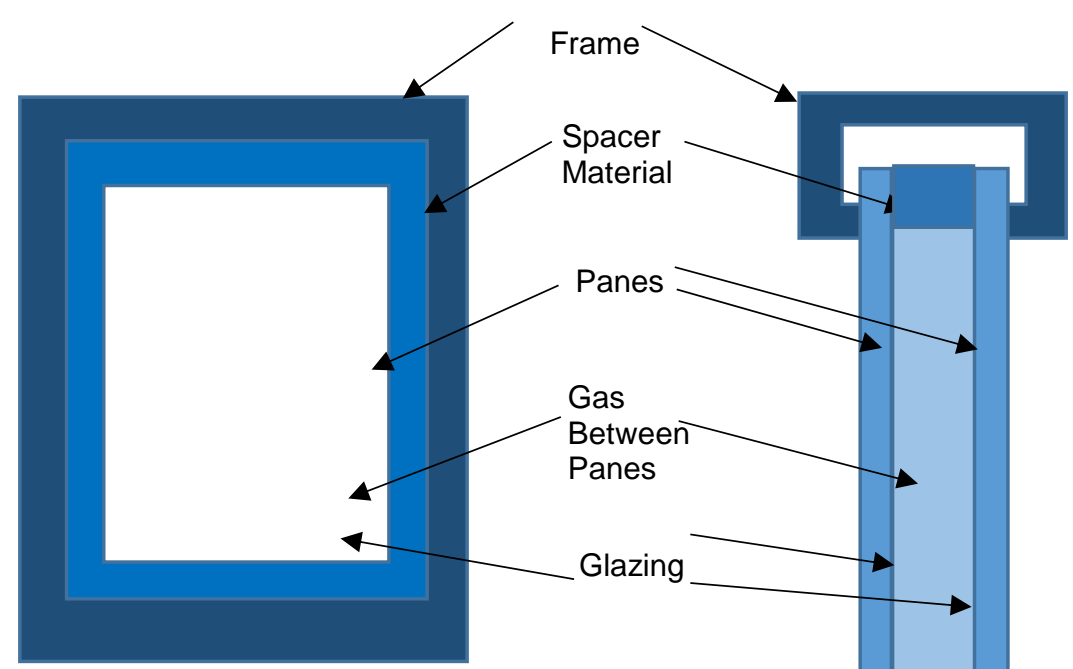

Figure 2: Factors effecting window performance

Table 1: List of major improvements in windows to improve energy efficiency [20], [21]

\begin{tabular}{|c|l|}
\hline $\begin{array}{c}\text { Glazing } \\
\text { Technologies }\end{array}$ & $\begin{array}{l}\text { low emissivity (low-e) coatings, tint glazing, switchable reflective glazing, } \\
\text { suspended particle device (SPD) film, }\end{array}$ \\
\hline Filling Technologies & Ar, Kr, Evacuated, Aerogel, Holographic Optical Elements \\
\hline Frame Material & Extruded Aluminum, Vinyl \\
\hline Coating Techniques & Pyrolytic coating, Sputtered coating \\
\hline Spacer Bars & steel reinforced polymer, glass fiber or structural foam with a polysulphide seal \\
\hline Glass Type & Low iron glass \\
\hline
\end{tabular}

\subsection{Window Technologies to Improve Window Energy Performance}

Various technologies have been adopted to improve the efficiency of the windows. Some of them are noted below:

\subsubsection{Low-Emissivity (low-e) coatings}

Low-e coatings reduce the long-wave radiative heat transfer between glazing layers leading to a $20-35 \%$ reduction in the U-values of glazed areas. They reduce solar 
transmission in the ultraviolet or UV range of the spectrum, as well as bring the glass surface temperature closer to the ambient temperature.

\subsubsection{Spectrally Selective Coatings or Tints}

Spectrally selective coatings or tints, also known as solar control tints are used to reduce the solar infiltration through the windows. They ensure that any absorbed solar gains are lost to the outdoors. Solar control tints do not affect the U-value of the window. They are most effective in hot climatic zones.

This study primarily studies window energy efficiency upgrades focusing on the effects of heating a double pane window on the building envelope and whether it improves the overall heating efficiency of the building.

Heated windows have been primarily used for providing thermal comfort near the windows, for removing frost off the airplane windows and automotive windshields, as well as refrigerator doors in departmental stores, apart from reducing moisture concentration on windows in operating theaters.

This study considers a double pane window with one of the inner faces having a transparent metallic costing that is heats up when electricity is passed through the terminals. The data collected during this study will be statistically analyzed to determine the influence of various factors that might be influencing the energy consumption of the building, and the effect of heated windows would be isolated. Based on the results of this study, the payback period for installation of a new heated window system would be estimated to determine whether the investment can be recovered within a reasonable amount of time. 


\subsection{Heated Windows}

A heated window is a window where the one of the panes of the glass has a transparent, electrically conductive coating that heats up whenever electricity is applied it. Typically, heated windows are used for improving comfort conditions along the perimeter of the building, for avoiding condensation/frost on the windows. They are typically used in buildings, food storage, automotive, as well as aerospace industry. A typical heated window is shown in Figure 3.

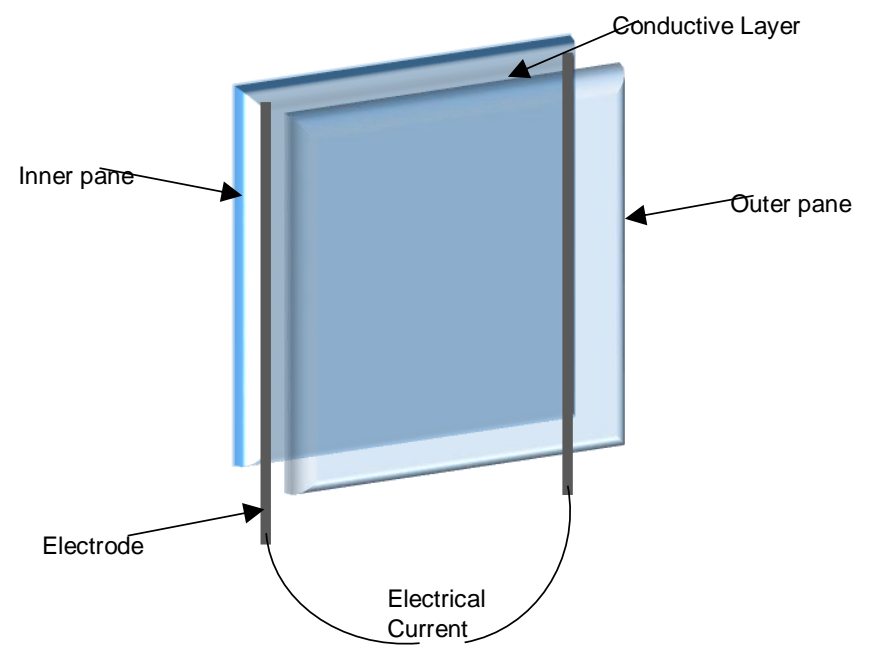

Figure 3: Schematic diagram of a heated window[22]

The effectiveness of high performance windows falls as the outside temperature goes down. When the outside temperature is $-18^{\circ} \mathrm{C}\left(-0.4^{\circ} \mathrm{F}\right)$, the indoor surface temperature of the glass is near $6^{\circ} \mathrm{C}\left(42.8^{\circ} \mathrm{F}\right)$ for a standard double pane window (clear glass + air + clear glass) while it is $11^{\circ} \mathrm{C}\left(51.8^{\circ} \mathrm{F}\right)$ for an energy-efficient double pane window (clear glass +argon +low-e glass). This leads to greater heat loss through the window via radiation. This is usually countered by raising the temperature on the thermostat. Another way this problem could be resolved is by raising the temperature of the inner pane of the 
window, while not letting any heat to flow towards the outer pane, thus forming a thermal barrier.

The average cost of a heated window is typically around 2.5 times the cost of a nonheated window, because of the presence of controls, apart from the necessary electrical connections in the window to heat up. A standard $8 \mathrm{ft}^{2}$ unheated double-pane window costs around $\$ 150$, while a heated window of the same area would cost $\$ 375$.

The advantages of heated windows are as follows:

1. Heated window reduces the cold draft around the window during winter time. This gives a sensation of warmth to people located close to the window.

2. Because of the reduction of cold draft around the window, people need not turn up the temperature on the heating system, thereby reducing the load on the room heater.

3. Heated windows are used in departmental stores and hospitals to avoid condensation on the windows. This condensation can lead to reduction in visibility in the freezers in the departmental stores, or lead to growth of mold or fungus.

\subsection{Need for Research}

While there is expansive research on various aspects of fenestration, like the work done by Bastion et al.[23], Apte et al. [24], Özkan et al. [25], Manz et al. [26], Lam et al. [27] about the window configurations based on region; by Gustavsen et al. [28] about window frames; or the suggestions about future technologies primarily dealing with improved glazing technologies by Arasteh et al. [29] and Jelle et al. [30], little has been done to address the fundamental issue of heat loss through convection from the 
window. While Aerogel technology may vastly help in this respect, it is far too expensive for commercial application. The general approach of the industry and the academicians towards the idea of heated windows has not been very positive, from an energy efficiency approach. It is generally believed that the heated windows are simply displacing the heat that would otherwise be put out by the central heating system because of the vicinity of the heating system to the cold ambient conditions, leading to greater heat loss. However, there are a limited number of studies performed on heated window technology from an energy efficiency standpoint, like the work done by Kurnitski et al.[31], and Moreau et al. [22], that show promise in the technology, contradicting popular beliefs. Myhren et al. [14] has suggested the possibility of energy savings by utilizing low temperature heating surfaces since they allow higher amount of heat to be radiated in the zone occupied by people, allowing the user to lower air temperature by up to $1.5^{\circ} \mathrm{C}\left(2.7^{\circ} \mathrm{F}\right)$ highlighting an added advantage to heated windows. Both Myhren et al. [14] and Gong et al. [15], suggested energy savings based on the position of heating source along the perimeter of the room. The idea of perimeter heating is fast picking up in Europe, with some houses having all the walls heated. It is believed that this approach would improve the building envelope. Due to the discrepancy in the understanding of effects of heated windows in energy savings beyond the effects of radiation, and the lack of sufficient research about the influence of heated windows on the building envelope, the study of effect of heated windows on the building energy envelope is warranted.

\subsection{Research Objectives}

The objectives of this research study are as follows: 
1. Develop an experimental model to test the effectiveness of a heated window in saving energy over a standard double pane window.

2. Determine whether heated double-pane windows are more energy efficient than standard double pane windows

3. Determine the conditions under which the heated double-pane windows would be more energy efficient than having a standard double pane window.

4. Perform tests on a building which has heated windows and compare results with that of the test set up to verify the results.

5. Perform a basic economic analysis of installing heated windows in a building.

\subsection{Conclusion}

Heat loss through windows is a significant component of the overall heat loss from a building. Advancements in the fenestration technology have been happening since 1970s since the realization that heat loss through windows cannot be taken for granted and can be reduced. Most of the current research focuses on improvements in the grazing technology and better frames for holding the windows. While the general belief is not favorable to the idea of perimeter heating through heated windows, but for moisture removal and ergonomic comfort around the windows, few studies have shown that heated window technology can save energy and be more efficient than standard double pane windows under specific conditions. 


\section{Chapter 2: Literature Review}

\subsection{Building Energy Models}

Building energy modelling (BEM) is a powerful tool that has been used for the past few decades in deciding the effectiveness of a building energy design for saving energy. Their complexity has increased over the years, due to the increase in the computational power of computers. However, the models are not always validated, and the validation studies are typically special cases that are not realistic. There is a difference between the what the models predict and how the system/design functions in real, as expressed by Ryan et al.[32], Borgstein et al. [33] and Virote et al.[34]. According to Zhao et al. [35],La Fleur et al. [36], and Pérez-Lombard et al. [37] one of the major factors that affect the energy use is the high variation in the energy use assumed for a user, vs actual behavior. Therefore, to get a better idea of how a system is functions in realistic conditions, an experimental setup is important. Borgstein et al. [33] defined various methods of evaluating energy performance of a building ranging from purely statistical with little information for the building required (Black Box Model), to based purely on building physics and highly dependent on user inputs (White Box Model), and something that is in the middle (Grey Box Model). The current study takes a Grey box approach towards identifying the energy efficiency performance of heated windows.

\subsection{Fenestration and Energy Efficient Window Technologies}

HVAC systems can consume as high as $50 \%$ of the total energy in a building, depending on the end use. Of this, windows can account for as high as $20 \%$ of the heat loss, which can increase, depending on the area covered by them on the building façade. 
Various studies have been performed on the effectiveness of different types windows, their orientation, size, as well as inclusion of shading, that could influence the energy efficiency performance. Studies have also been performed about the effect of manual control on windows, which can also effect the building efficiency.

Yasar et al.[38], Bojic et al.[39], Yoo et al.[40], Tsikaloudaki et al.[41], Manz et al.[26], and Hassouneh et al.[42], all talk about the effect of various types of windows and glazing technologies, apart from smart windows, in saving energy in various climatic zones across the world.

According to Yasar et al. [38] and Bojic et al. [39], double pane windows with low-e\#2 coating and clear glass gave the best energy savings over the whole year, and the best performance during winters. On the other hand, smart glazing units with absorptive + reflective + low-e coating performed best in the hotter climate. Tints and reflective coatings were found to be preferable for warmer climates where the solar heat gain was high, while clear coatings were preferable in cooler climates, where the solar heat gain is low.

According to Tsikalousaki et al. [41], higher thermal transmittance is preferred in hotter climate, along with sufficient shading over the window, especially in houses/buildings which lack a heating system and depend on natural cooling. It was also mentioned that ventilation patterns influenced the heat loads in the buildings.

Manz et al. [26] found that double pane windows performed at their best in south facing facades and performed the worst in north facing facades in the northern hemisphere, due 
to higher solar gains facing south, and lower solar gains facing north. They also found that older double pane windows were far more inferior to the newer ones, possibly due to the advancements in the window as well as frame technology. Also, greater thermal mass inside a well-insulated building air-tight building ensured lower temperature fluctuations.

Hassouneh et al. [42] had suggestions that finetuned on the suggestions by Manz et al. [26], Yasar et al. [38] and Bojic et al. [39] . According to them, highest energy savings can be achieved by varying the type of glazing and window area based on the direction. Using a clear type double paned window with low-e coating facing north and a clear glass type double pane window without low-e coating facing east, west, or south gave the best energy efficient performance. Also, increasing the area of the windows in the east, west, and south side, and reducing the window area in the north side, depending on the glazing, was more energy efficient.

\subsection{Floor and Perimeter Heating}

Floor heating, a system that uses embedded pipes in the floor to heat a building, has been used for hundreds of years. However, with the advent of panel units in the last century, they went out of fashion. Lately, however, it is again being implemented. According to Maerefat et al.[43], floor heating increases both thermal comfort. On the other hand, Ren et al [44], and Causone et al.[45] have said that the energy efficiency for heating also increases due to the utilization of a low temperature heating medium (water). Lower water temperature means increase in efficiency of the boiler, thus proportional energy savings. The lower water temperature also opens up the possibility of using solar, 
or waste heat for heating the water, as suggested by Ren et al.[44], and Zhai et al.[46]. Also, lack of blowers makes the system quiet.

However, presence of furniture, including carpeting over the floor can reduce the efficiency of the floor heating system, as explained by Fontana [47], and Sattari et al.[48]. Karabay et al [49], has suggested that in wall heating, also commonly referred as perimeter heating, can have similar effects as floor heating, while also being more efficient in rooms with furniture. In a retrofitting study done by Wang et al. [50], savings as high as $50 \%$ were achieved over the existing high temperature district heating system.

\subsection{Heated Windows}

The effects of perimeter/wall heating of buildings is well documented [44], [47]-[49], [51]. However, the effect of heated windows on the building envelope and energy consumption is not well documented. Most of the studies focused on using purely numerical methods in controlled conditions. Studies focused on heated windows have not considered a realworld scenario to observe the window behavior. Also, no energy modeling software was utilized to study the behavior of heated windows.

Freestone [12], Lyons et al. [13], and Myhren et al. [14], have studied the effect of perimeter heating to improve the thermal comfort in the room.

According to Myhren et al.[14], during cold weather season, the cold draughts caused by the cold window panes may be avoided by installing a radiating heating system underneath the windows. The cold air down-flow would meet the rising air form the radiators, and mix together, before reaching the occupied zone, thus giving a sensation 
of warmth. Myhren et al. [14] also suggested that low temperature heating surfaces with high emission surfaces can create an effective heating system since they allow a large contribution of radiation to reach people, and lower air temperature is needed to reach comfort conditions. Freestone [12] discussed about increasing the Mean Radiant Temperature (MRT), by increasing the wall, ceiling, and floor temperatures, to improve MRT for occupants close to windows.

According to Lyons et al. [13], windows are influential in defining the comfort of a building's occupants when they are very hot or cold, and the occupants are very close to the window. They believed that the current methods of modeling may under-predict discomfort caused by windows.

Gong et al. [15] found that when radiant heating systems are placed close to a window, they increase the heating load by up to $3.6 \%$ in an inadequately ventilated space, compared to $100 \%$ convective heating. However, placing a radiator near the window did improve the comfort level in a space.

In the studies performed by Freestone [12], Lyons et al. [13], and Myhren et al. [14], attention was given to the effect of radiation heat transfer, and limited emphasis was placed on the deterioration of comfort due to the cold draft created close to unheated windows due to convection. Due the relatively low temperatures at which living and working spaces are maintained, the effect of radiation would be minimal and heat loss through convection would take precedence. 
Studies that focus primarily on energy efficiency performance of windows include those by Kurnitski et al. (2004) [31], in the Master's thesis by Endika A. Ollokiegi [52], and Moreau et al. (2008) [22].

In the Master's thesis by Ollokiegi [52], the effect of electrically heated windows on the thermal comfort and energy use aspects for a building under construction were discussed. The results were simulated using a software tool named IDA. It was shown that heated windows improved the comfort conditions within the room, primarily due the predominant nature of heat transfer involved, radiation vs conduction. It was however not clear whether the study considered the building to be heated only using the heated windows, or whether there was an external heating source and the windows were supplemental heating sources to improve comfort conditions around the windows. Also, there was no conclusions drawn on whether energy efficiency improved by using heated windows, or it deteriorated.

Both Moreau [22], and Kurnitski [31] focused on comparing the performance of the windows when the heating was turned on, and turned off. All three modes of heat transfer; conduction, convection, and radiation, were considered. Moreau et al. [22] however also included the effect of the incident solar radiation and the solar fluxes absorbed by the surfaces. While Moreau et al. [22] simulated their results using the software, WINDOW, developed by Lawrence Berkley National Lab (LBNL), Kurnitski et al. [31] performed his own calculations, based on a hypothetical room with a heating source at the center. Neither of the studies performed any experimental studies to arrive at the conclusions. Kurnitski et al. [31] noted that their results were significantly different from some 
preliminary experiments performed by Finnish Research Center VTT, although no data from this study was provided.

\subsection{Conclusion}

Based on the studies performed thus far with respect to heated windows, a major focus has been on establishing the advantages from a radiation heat transfer source point of view, as well as improvement in the comfort conditions of the room. Most studies suggested energy efficiency improvement by reducing the temperature of the air within the room by over $1^{\circ} \mathrm{C}$ because of the heating effects of radiation. Also, all tests were based on mathematical studies, instead of experimental studies to verify the work. The study performed by Kurnitski et al. [31] noted that their results were significantly different from the preliminary experiments performed by Finnish Research Center VTT, although no reference to the data from that study was provided. Also, the data could not be traced for reference.

Since the temperatures in a room are well below $80^{\circ} \mathrm{F}$ to maintain comfort conditions during the winter season, the actual effect of a window heated to the room temperature is supposed to be low. This is under the assumption that the windows are not being used as the primary source of heat for the room, but being used for developing a thermal barrier to reduce heat loss. The most dominant source of heat transfer under such conditions would be convectional heat transfer from the windows to the air. Also, due to the air gap within a double pane heated window, it is expected that the heat loss from the hot to the cold side would be low, thereby improving the energy efficient performance of the heated window. 


\section{Chapter 3. Data Collection Methodology}

\subsection{Research Approach}

The project was divided in four phases, following literature review.

Phase 1: Generation of BEM model

Previous studies done with respect to heated glass windows were analyzed, and the Department of Energy's Quick Energy Simulation Tool (eQUEST $\left.{ }^{\circledR}\right)$ was studied. It was explored whether eQUEST $\AA$ could be used to develop a (Building Energy Model) BEM for this study. However, due to the lack of fine controls in the software, and, the lack of tools pertaining to the unique nature of operation of heated windows, this work was abandoned. eQUEST ${ }^{\circledR}$ is a very useful tool in getting the overall performance parameters of a building, but not suitable for considering the performance of specific elements of the building under different conditions, like the windows, doors, or the walls. Figure 4 shows a schematic of the single room building with one window, developed to study the effects of a heated window.

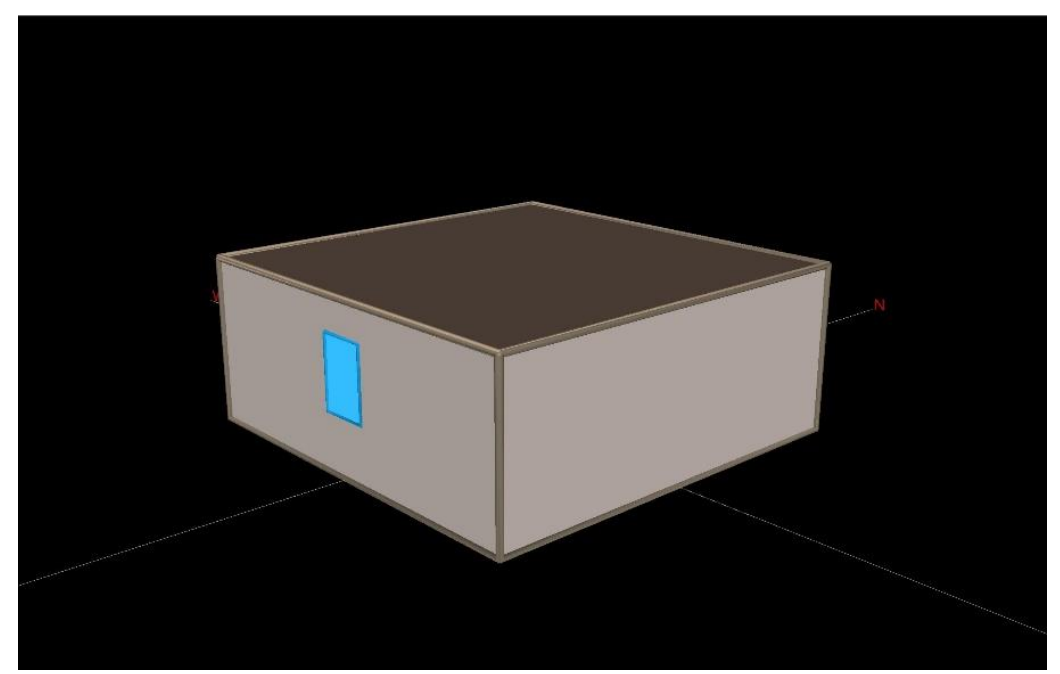

Figure 4 Schematic of the building modeled in eQuest ${ }^{\circledR}$ 
Phase 2: Development of heat transfer model for testing the heated window characteristics

A heat transfer model which could simulate the characteristics of the window was attempted to be developed. The model took inputs like the temperature of the window panes on the exposed sides, power input to the window in watts, conduction and convective heat transfer coefficients, room and ambient (outside) temperature, glass thickness, and area of the glass. The heat flow through the window were projected using equations for conduction and convection. The results were considered acceptable if the total heat output from both sides of the window based on the calculated temperatures matched. During the testing of the heat transfer model, it was noticed that the temperatures of window panes were vastly varying for very minor changes in temperature. This showed that the heat transfer model was not working properly. It is surmised that this may be happening due to the complex and inter-dependent nature of the variables which could not be fully encompassed by a simple heat transfer model. Since the heat transfer model would not affect the outcome of this study, it was decided not to pursue it further, due to the time constraint it posed. A screenshot of the heat transfer model can be seen in Figure 5. 


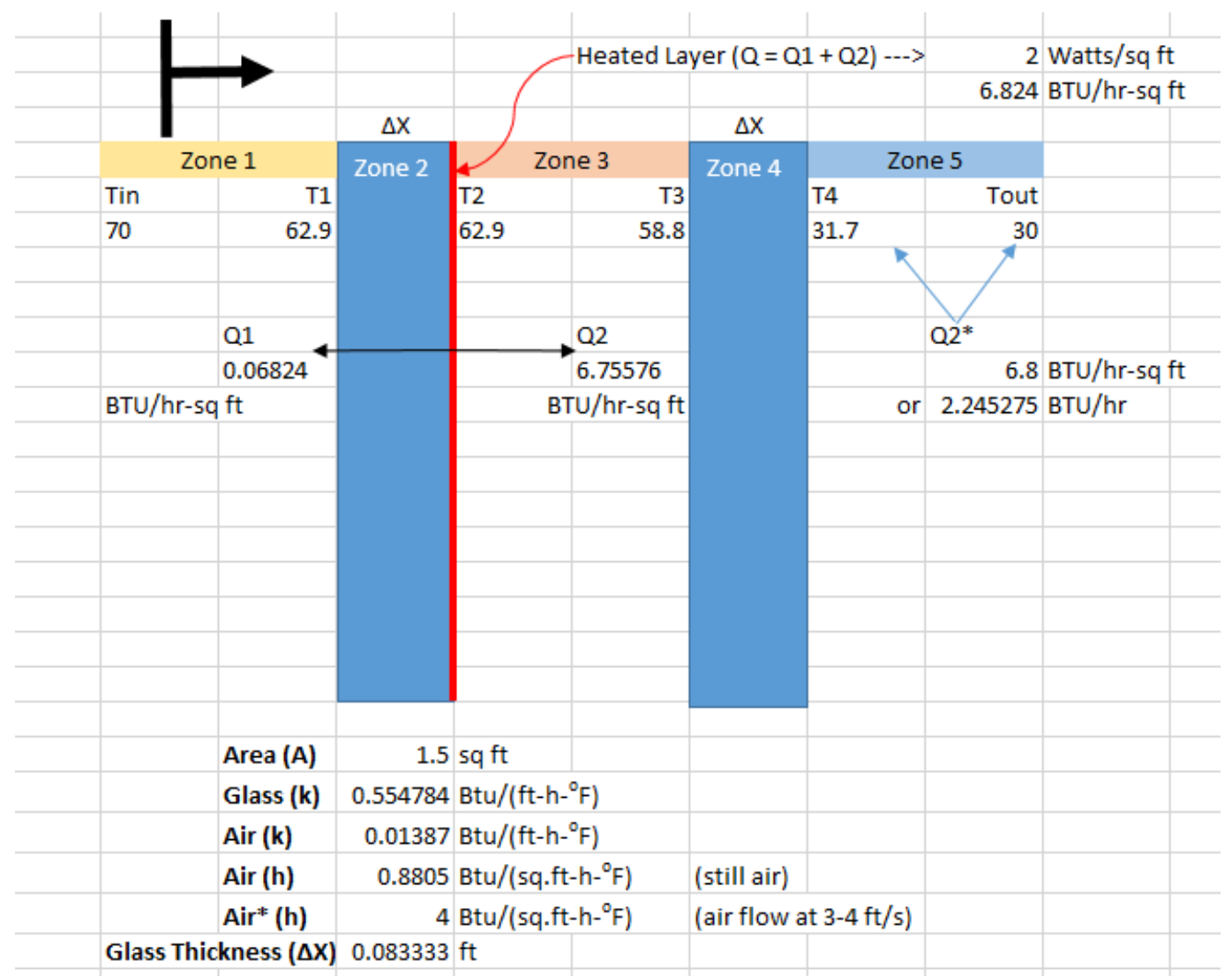

Figure 5 Screenshot of Heat Transfer Model

Phase 3: Development of Experimental model and testing of the heated window characteristics

An enclosed space for isolated cooling was constructed, with a heated window installed on one of the walls. The model was tested under various conditions and it was determined where to install the thermocouple based temperature sensors, to record the temperature changes in the window when it was heated and/or cooled. Appropriate cooling apparatus was determined and tested to zero in on the size. Further details of the experimental setup are discussed in section 3.2. 
Phase 4: Data collection and analysis for heat loss through the experimental setup, with, and without heating the glass window.

A testing methodology was devised and appropriate temperature and power input data collected, based on some preliminary experiments on the system. The windows were never heated past $90^{\circ} \mathrm{F}$ since buildings are seldom heated to this level This data was analyzed and processed to determine the performance characteristics of the heated window.

Phase 5: Data collection from a building with heated glass windows during winter.

The performance of a building with heated windows was attempted to be determined by installing temperature and current data loggers at a small manufacturing facility with heated windows, over the winter season, over a period of 2 and half months, with the windows turned on, and turned off. However, due to lack of current/temperature controls on the windows, and the highly drafty nature of the building due to its age, the data was found to be inconclusive and the endeavor had to be abandoned. Figure 6 shows a schematic of the building where the temperature data was collected. 


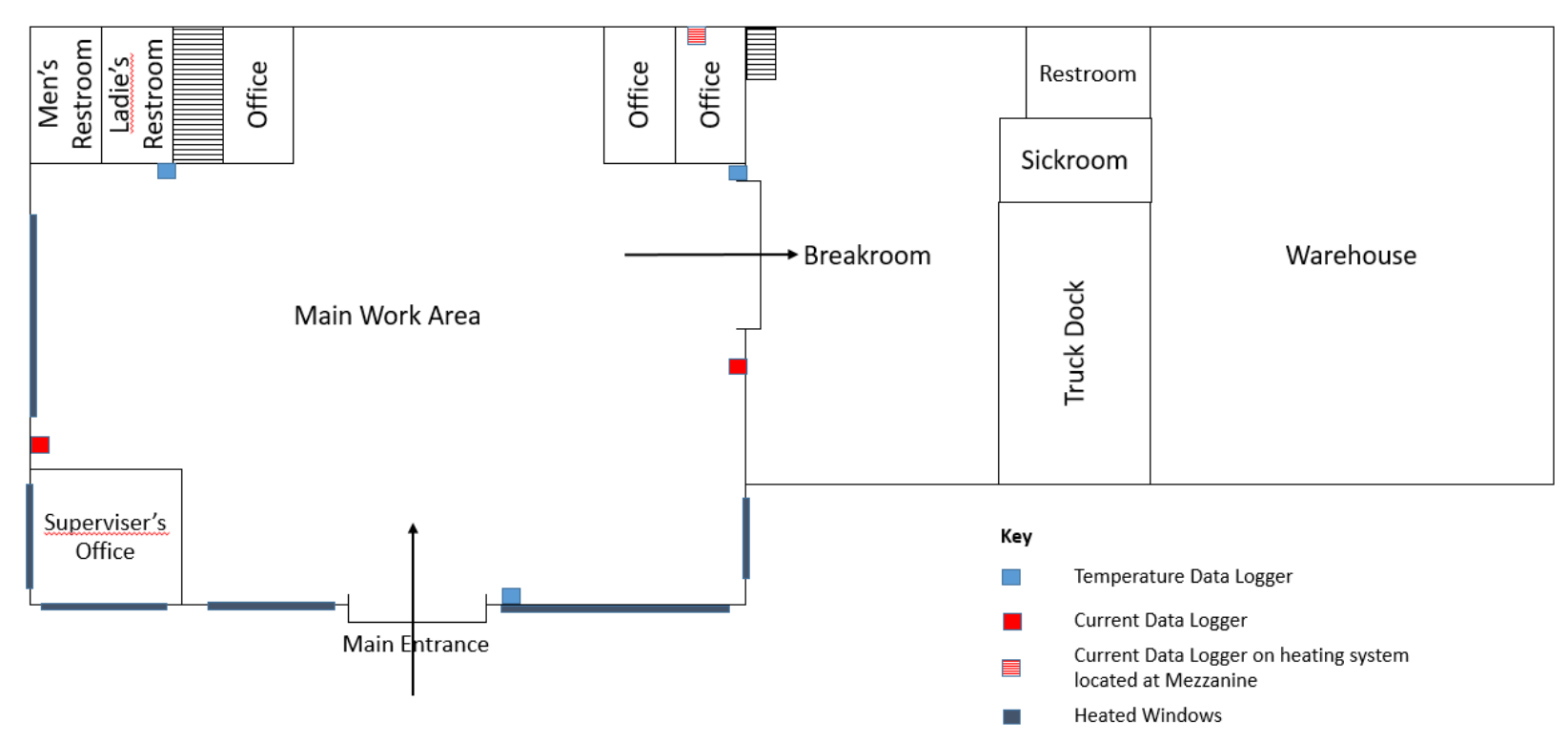

Figure 6 Building Schematic where temperature data was collected

\subsection{Description of Experimental Setup}

The experimental setup is shown in Figure 7. A cubic box of $8 \mathrm{ft}^{3}$ was constructed using R-5 insulation foam boards. A standard double pane window with the heated side facing outwards was installed on one of the sides of the box. The window has the dimensions 12 " $x 18$ " and was 1 inch thick. The box also has a resealable opening on the top for access to the inside of the box. This access was used to place gel based ice-packs for cooling the box, apart from installing a small fan inside the box to facilitate cooling of the face of the window inside the box. The gel based ice packs were preferred due to their ease of use compared to ice, which may leak once melted. Also, the ice packs lasted through the length of the experiment, and were easier to transfer. Figure 8 shows one such pack used in the experiment. An important note to be made here is that the box is supposed to simulate a temperature gradient across the window, to simulate the heat loss through the window during the heating season. The inside of the box represents the 
outside condition during winter time while the outside of the box, placed within a conditioned room, represents the inside of the room. Therefore, the heated side of the window is facing outside (towards the room), rather than inside (towards the ice packs). A fan, running at a constant speed was placed inside the box to blow over the ice packs, towards the window, to accelerate the process of cooling the box, and create forced convection within the box, mimicking the conditions outside during winter. To measure the temperature of the air within the box (for comparison with box temperature) as well as the velocity profile across the window, an ALNOR® Model 8585 anemometer was used, shown in Figure 9. Three equidistant holes were drilled 2 inches away from the face of the window and the velocity of the air blowing from the fan was measures at 9 points, across the face of the window for various power inputs. The air temperature was compared with the box temperature to determine any errors in the data.

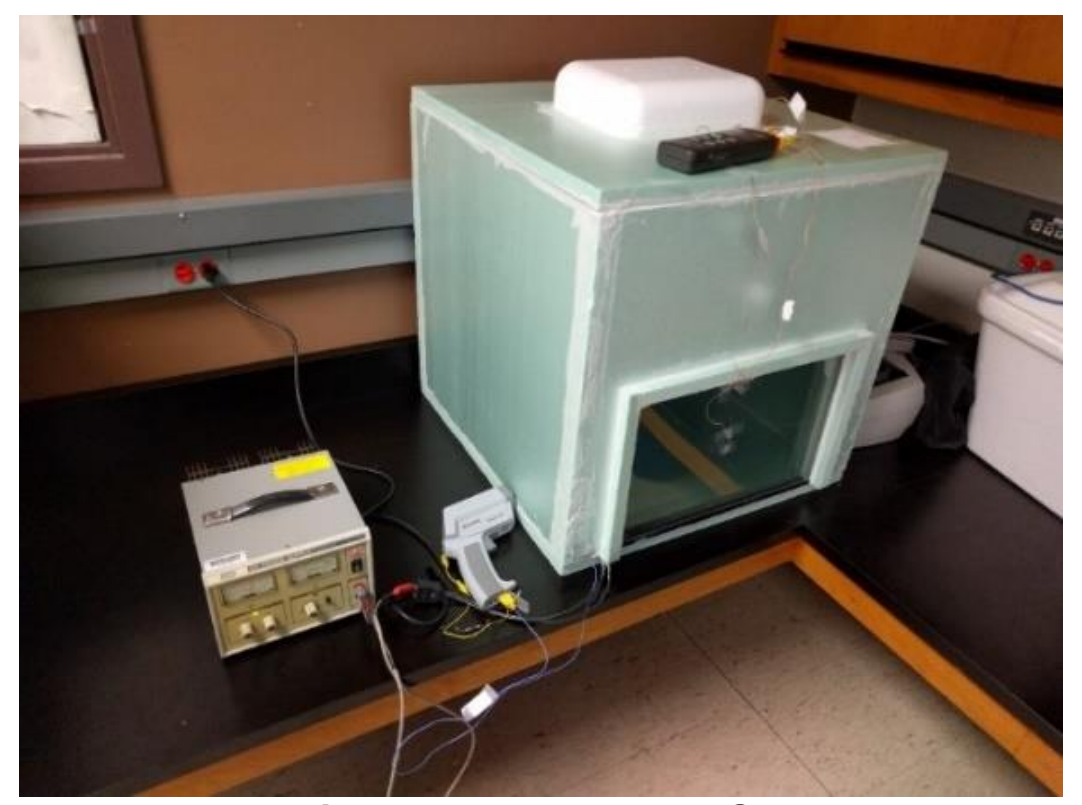

Figure 7 Experimental Setup 


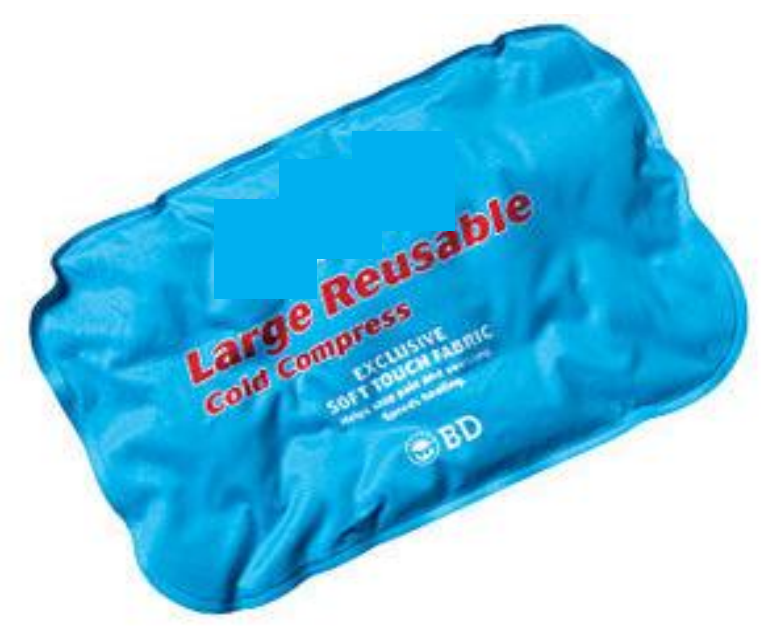

Figure 8 Ice pack used in the experiments

To measure the temperature of the window panes, as well as the temperature inside the box, K-type thermocouples were installed. One thermocouples were installed on the outside face of the window, and two on the inside. A thermocouple was installed on the face of the inside of the box, to provide the temperature of the box. It is assumed that the inside surface of the box is at the same temperature as the air inside the box. The temperature of the thermocouples attached on the window panes is detected using the Omega $\AA^{\circledR}$ Datalogger Thermometer, as shown in Figure 10, while the temperature of the box is detected with the Raytek® Rangefinder MX2 thermal gun, as shown in Figure 11.

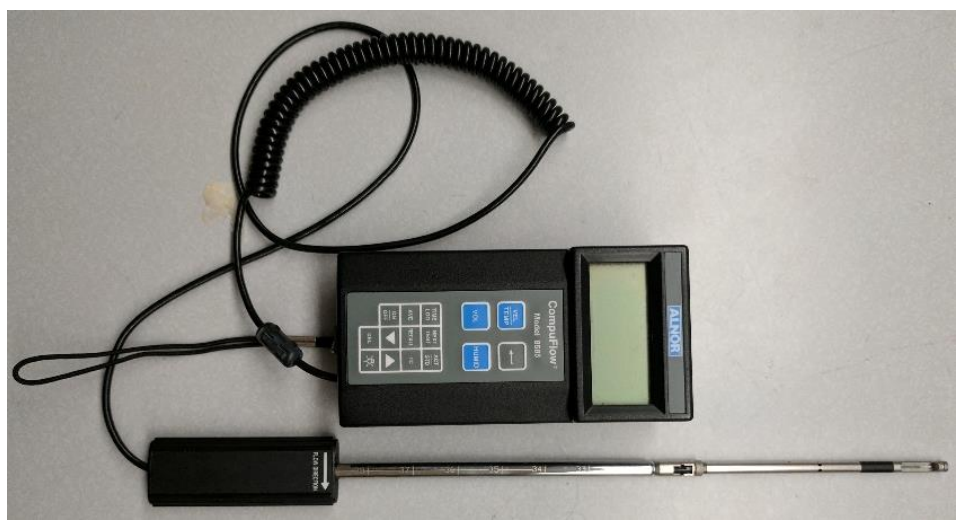

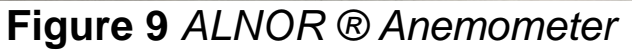




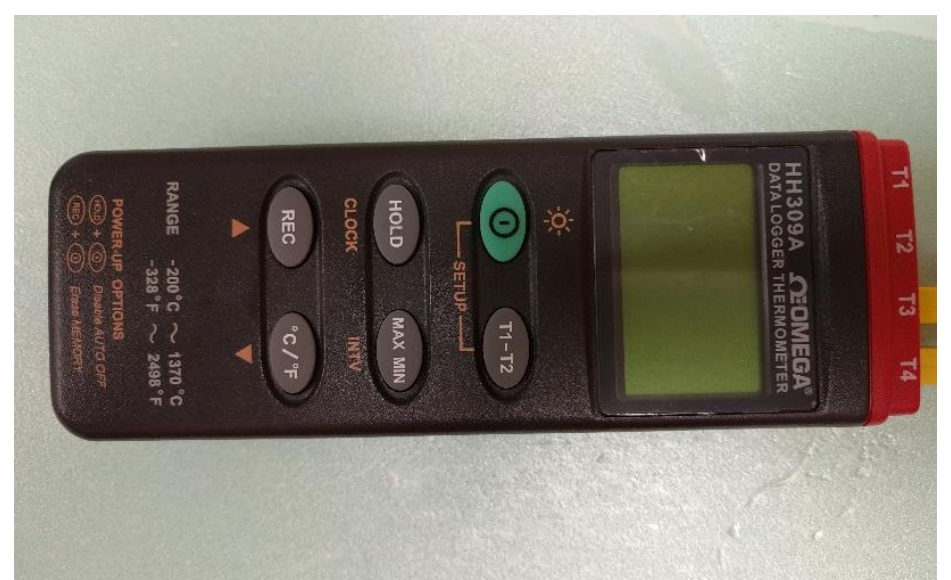

Figure 10 Temperature data logger

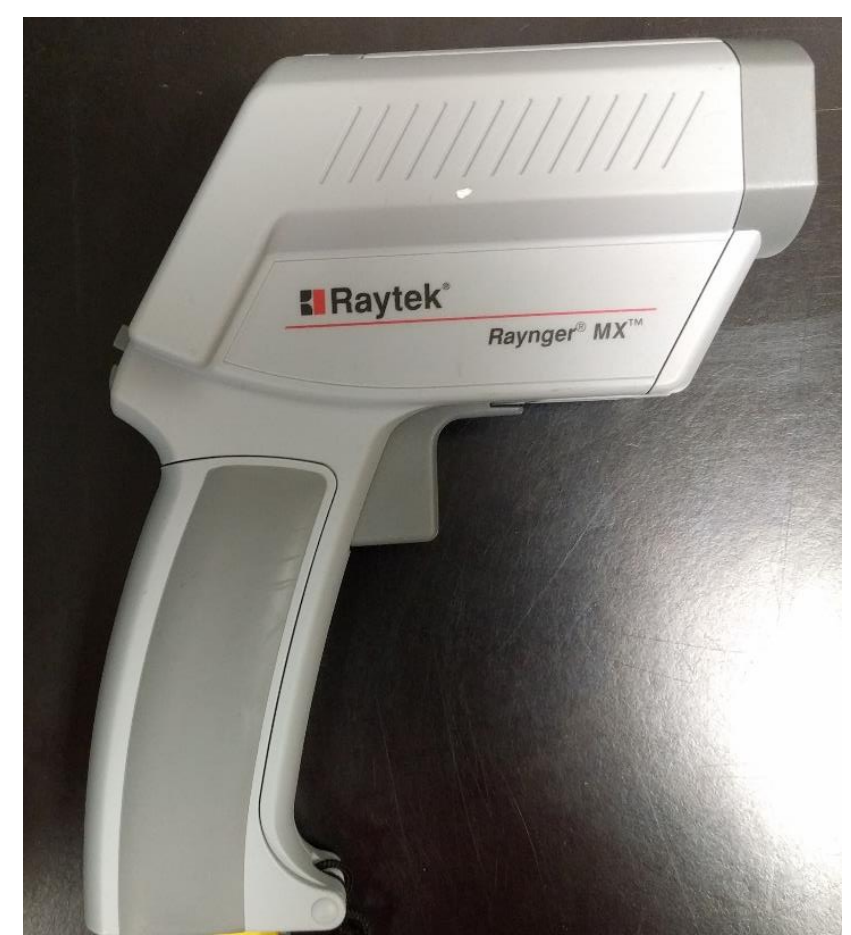

Figure 11 Thermal gun

Power input to the window is provided using $\mathrm{EMCO} \otimes \mathrm{DC}$ power supply with output current and voltage controls as shown in Figure 12. Either the current, or the voltage from the DC power supply can be controlled at a time. Both cannot be controlled simultaneously at the same time. So, only current was controlled for the experiment, in steps of $0.1 \mathrm{~A}$. 


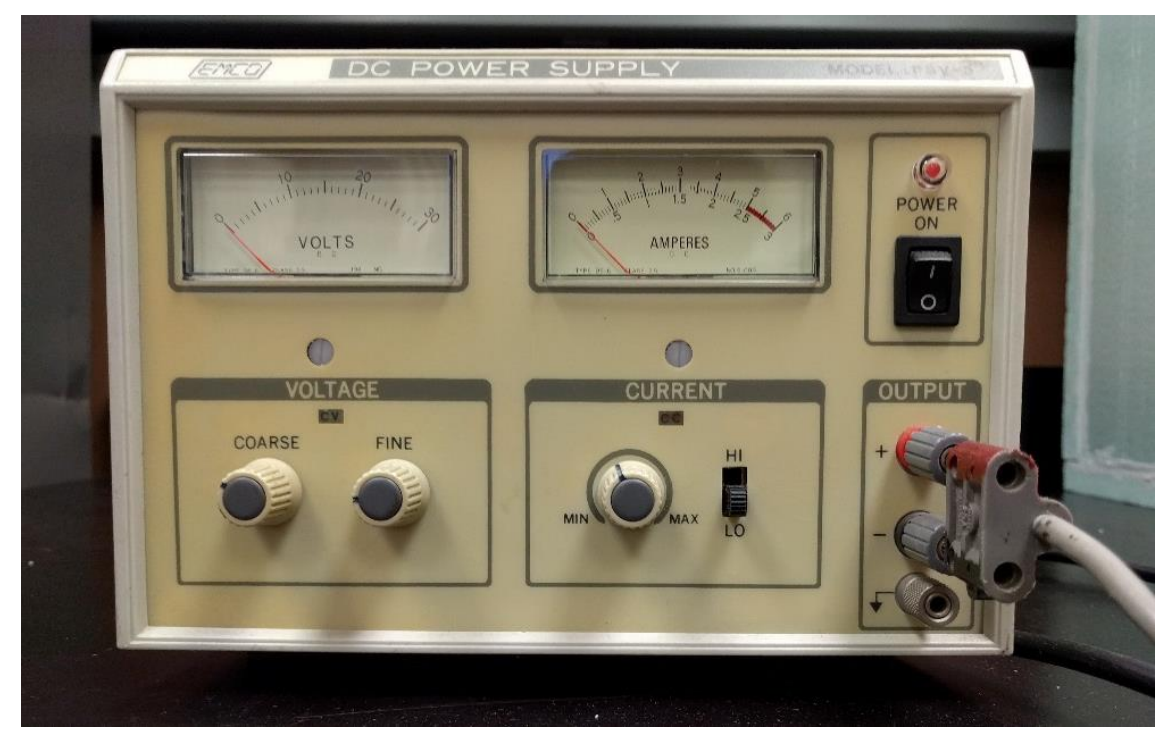

Figure $12 E M C O{ }^{\circledR} D C$ power supply

\subsection{Data Collection Methodology}

Window performance data was collected when the window heated, and gel-based ice packs that were frozen overnight, placed inside the box. Data was also collected when the window was not heated, and the frozen gel packs were placed inside the box for comparing the results of the heated window vs a non-heated window. A current of $0.1 \mathrm{~A}$ to $0.8 \mathrm{~A}$ was applied as an input. Voltage could not be simultaneously controlled using the available equipment, so it could vary with the current input. It was found during initial testing that the window temperature was around $90^{\circ} \mathrm{F}$ when a current of $0.8 \mathrm{~A}$ (at $10 \mathrm{~V}$ ) was applied. A temperature beyond $90^{\circ} \mathrm{F}$ is believed to not be representative of a practical use case.

Pre-frozen ice packs were placed inside the box and the circulation fan was turned on. The window was initially heated for $20 \mathrm{~min}$, to ensure that the temperature of the window and the box reached a steady state condition. Thereafter, the window was heated for 8 
min every time the power input was increased. The ice-packs in conjunction with the fan provided a sufficient temperature gradient across the window. The velocity of air was measured and noted at 9 locations at 2 inches away from the window using the anemometer by inserting the probe through one of the three holes and extending across the face of the window. Temperature of the windows as well as the inside surface of the box was recorded at intervals of $8 \mathrm{~min}$, before raising the window temperature.

Using the temperature of the box, both sides of the window panes, and the room temperature, as well as the area of the window faces, the heat lost from the window was calculated.

\subsection{Conclusion}

After implementing the plans for experimental work, the following conclusions were drawn:

1. The highly interdependent nature of the variables caused instability in the calculated values of temperature of the window panes. Due to the large variation in the temperatures for small changes in power input, it was concluded that simple heat transfer model may not be sufficient to develop a good representation of the system.

2. e-Quest ${ }^{\circledR}$, while being a useful tool in predicting the overall building energy envelope, did not have necessary controls to fine tune specific aspects of the model. Therefore, the effects of a heated window based on changing electrical input, could not be determined. 
3. The building chosen for performing the verification tests of the experimental model did not have thermostat based controls on the windows. The windows were operating at a very high power input, and thus were running extremely hot. This, coupled with the very old and drafty construction of the building made the energy consumption data with the heated window turned on, undiscernible from the energy consumption data when the system was turned off.

4. The experimental model constructed with an operational heated window and project board, was found to be the best possible representation of a practical system, within the limited resources available for the work. In this setup, the power input to the window could be varied, and a temperature gradient could be created across the window using ice-packs. 


\section{Chapter 4. Results, Discussion, Conclusion, and Future Work}

For the experimental setup, as shown in Figure 13, temperature of the window on in Zone 5, which represents the inside of the box and is cooled to low temperatures using frozen gel-based ice packs, and a circulation fan, was collected at two points, at the center of the window and two inches about it. Temperature of the side of window facing Zone 1 was measured at only one location, at the center of the window. Zone 1 represents the room and is maintained by the university's central air conditioning system between $70^{\circ} \mathrm{F}$ and $80^{\circ} \mathrm{F}$. Zone 3 is the air-gap between the window panes. Zone 2 and 4 are window panes. During the experiment, the temperature of the heated layer, $T_{2}$, and the inside face of the non-heated pane, $T_{3}$, could not be measured since they were sealed off. Only the temperatures of the room, $\mathrm{T}_{\mathrm{amb}}$; face of glass facing the room (non-heated outside face of the heated pane), $T_{1}$; face of glass facing the box (outside face of the non-heated pane), $T_{4}$; and temperature inside the box, $T_{\text {box }}$, could be measured. $Q_{1}$ represents the heat flowing inside the room and $\mathrm{Q}_{2}$ represents the heat flowing outwards. $\mathrm{Q}^{*}$ is the eventual heat loss to the atmosphere. The total amount of energy supplied to heat the window, $Q$, equals $Q_{1}+Q_{2}$. 


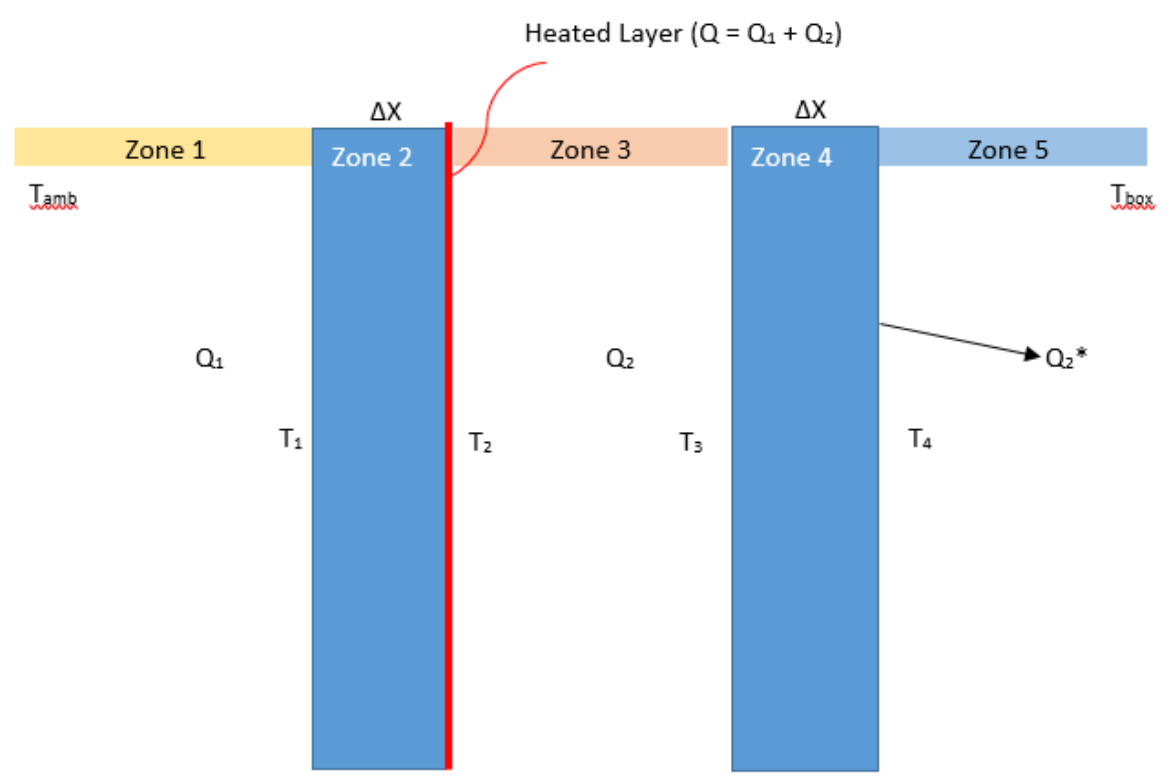

Figure 13 Schematic Diagram of the Experimental Setup

In a double pane window, zones 1, 3, and 5, have convectional heat transfer as the dominant mode of heat transfer with negligible heat transfer through conduction. Zone 1 and 2 have conduction as the dominant mode of heat transfer. Radiation is negligible due to the low temperatures and therefore ignored.

\subsection{Window Heat Loss Calculation}

The convective heat loss from the window may be calculated using the following equation:

Heat Loss $=$ Temperature Difference $\times$ Area $\times$ Convective Heat Transfer Coefficient Or,

$$
\mathrm{Q}=\Delta \mathrm{T} \times \mathrm{A} \times \mathrm{H}
$$

In the formula above, the heat transfer coefficient is dependent upon the velocity of the air around the window. Higher the velocity, higher the heat transfer coefficient. The temperature of the heated window is not raised above $90^{\circ} \mathrm{F}$, to keep it in line with the 
temperatures at which rooms are typically maintained. However, for a few tests, the window temperature was taken close to $115^{\circ} \mathrm{F}$ to explore the effects of window temperature on heat loss. It was assumed that all the power input to the window was converted into heat with no losses. The property and dimensions of the window used in this study are shown in Table 2. The velocities measured at 9 locations across the window is shown in Table 3. The average of these velocities was used throughout the study. Properties of air used for the calculation of heat loss through the window are shown in Table 4. The heat loss through the unheated double pane window, is shown in Table 5. The heat loss through the window when it is heated, is shown in Table 6. Some of the raw data is available in the Appendix.

Table 2 Properties of the window used in the study

\begin{tabular}{|l|c|}
\hline Thermal Conductivity of Glass $\left(\mathrm{k}_{\text {glass }}\right)$ & $0.554784 \mathrm{Btu} /\left(\mathrm{ft}-\mathrm{h}-{ }^{\circ} \mathrm{F}\right)$ \\
\hline Thickness of each pane $(\Delta \mathrm{X})$ & $0.0833 \mathrm{ft}$ \\
\hline Window dimensions & $12{ }^{\prime \prime} \times 18^{\prime \prime}$ \\
\hline Area of the window $(\mathrm{A})$ & $1.5 \mathrm{ft}^{2}$ \\
\hline R-Value of Window & $\mathrm{R}-3$ \\
\hline
\end{tabular}

Table 3 Velocity profile across the face of the window for various power inputs

\begin{tabular}{|c|c|c|c|c|c|c|c|c|}
\hline $\begin{array}{c}\mathbf{V}_{\mathbf{1 1}} \\
\mathbf{f t} / \mathbf{m i n}\end{array}$ & $\begin{array}{c}\mathbf{V}_{\mathbf{1 2}} \\
\mathbf{f t} / \mathbf{m i n}\end{array}$ & $\begin{array}{c}\mathbf{V}_{\mathbf{1 3}} \\
\mathbf{f t} / \mathbf{m i n}\end{array}$ & $\begin{array}{c}\mathbf{V}_{\mathbf{2 1}} \\
\mathbf{f t} / \mathbf{m i n}\end{array}$ & $\begin{array}{c}\mathbf{V}_{\mathbf{2 2}} \\
\mathbf{f t} / \mathbf{m i n}\end{array}$ & $\begin{array}{c}\mathbf{V}_{\mathbf{2 3}} \\
\mathbf{f t} / \mathbf{m i n}\end{array}$ & $\begin{array}{c}\mathbf{V}_{\mathbf{3 1}} \\
\mathbf{f t} / \mathbf{m i n}\end{array}$ & $\begin{array}{c}\mathbf{V}_{\mathbf{3 2}} \\
\mathbf{f t} / \mathbf{m i n}\end{array}$ & $\begin{array}{c}\mathbf{V}_{\mathbf{3 3}} \\
\mathbf{f t} / \mathbf{m i n}\end{array}$ \\
\hline 65 & 168 & 108 & 52 & 230 & 75 & 49 & 110 & 106 \\
\hline 80 & 170 & 94 & 60 & 230 & 97 & 45 & 95 & 65 \\
\hline 85 & 160 & 83 & 65 & 225 & 88 & 59 & 90 & 70 \\
\hline 50 & 114 & 90 & 70 & 245 & 80 & 45 & 86 & 63 \\
\hline 72 & 180 & 80 & 55 & 215 & 95 & 47 & 87 & 64 \\
\hline 66 & 162 & 85 & 65 & 216 & 83 & 50 & 104 & 90 \\
\hline 68 & 165 & 81 & 59 & 193 & 79 & 49 & 90 & 68 \\
\hline 70 & 164 & 85 & 65 & 201 & 68 & 50 & 98 & 80 \\
\hline Average & & & & & \multicolumn{2}{c|}{$\mathbf{1 0 0} \mathbf{f t} / \mathbf{m i n}$} \\
\hline
\end{tabular}


Table 4 Heat Transfer Properties of air[53]

\begin{tabular}{|c|c|}
\hline Convective heat-transfer coefficient of still air & $1.46 \mathrm{Btu} /\left(\mathrm{ft}^{2}-\mathrm{h}-{ }^{-} \mathrm{F}\right)$ \\
\hline Convective heat-transfer coefficient of $15 \mathrm{mph}$ air & $6 \mathrm{Btu} /\left(\mathrm{ft}^{2}-\mathrm{h}-{ }^{\circ} \mathrm{F}\right)$ \\
\hline Convective heat-transfer coefficient of $1.14 \mathrm{mph}$ air (interpolated) & $1.49 \mathrm{Btu} /\left(\mathrm{ft}^{2}-\mathrm{h}-{ }^{\circ} \mathrm{F}\right)$ \\
\hline
\end{tabular}

Table 5 Heat loss through the unheated double pane window

\begin{tabular}{|c|c|c|c|c|}
\hline \multirow{2}{*}{$\begin{array}{c}\text { Time } \\
(\mathbf{m i n})\end{array}$} & \multicolumn{2}{|c|}{ Temperature ( $\left.{ }^{\circ} \mathbf{F}\right)$} & \multirow{2}{*}{$\begin{array}{c}\text { Room } \\
\text { Temperature } \\
\left({ }^{\circ} \mathrm{F}\right)\end{array}$} & $\begin{array}{c}\text { Heat-loss to } \\
\text { box (Btu/hr) }\end{array}$ \\
\cline { 2 - 3 } & Inside Pane & Inside Box & $\mathbf{T}_{\text {amb }}$ & \\
\cline { 2 - 3 } & $\mathbf{T}_{\text {in }}$ & $\mathbf{T}_{\text {box }}$ & 72 & 0.45 \\
\hline 0 & 71.8 & 71.6 & 72 & 39.45 \\
\hline 10 & 60.25 & 42.6 & 72 & 13.41 \\
\hline 20 & 34.4 & 28.4 & 72 & 4.36 \\
\hline 30 & 30.35 & 28.4 & 72 & 6.03 \\
\hline 40 & 29.5 & 26.8 & 72 & 6.93 \\
\hline 50 & 29.5 & 26.4 & 72 & 6.48 \\
\hline 60 & 30.1 & 27.2 & 72 & 5.25 \\
\hline 70 & 30.75 & 28.4 & 72 & \\
\hline
\end{tabular}

Table 6 Heat loss through the heated double pane window

\begin{tabular}{|c|c|c|c|c|c|c|c|c|}
\hline \multirow{3}{*}{$\begin{array}{l}\text { Time } \\
(\min )\end{array}$} & \multirow{3}{*}{$\begin{array}{l}\text { Power Input } \\
\text { (Watts) }\end{array}$} & \multirow{3}{*}{$\begin{array}{l}\text { Power Input } \\
\text { (btu/h) }\end{array}$} & \multicolumn{4}{|c|}{ Temperature $\left({ }^{\circ} \mathrm{F}\right)$} & \multicolumn{2}{|c|}{$\begin{array}{l}\text { Heat Output Rate } \\
\text { (btu/h) }\end{array}$} \\
\hline & & & $\begin{array}{c}\text { Unheated } \\
\text { Pane }\end{array}$ & $\begin{array}{c}\text { Inside } \\
\text { Box }\end{array}$ & $\begin{array}{c}\text { Heated } \\
\text { Pane }\end{array}$ & Ambient & $\begin{array}{c}\text { Inside } \\
\text { Box }\end{array}$ & $\begin{array}{l}\text { Outside } \\
\text { Box }\end{array}$ \\
\hline & & & $T_{\text {in }}$ & $T_{\text {box }}$ & $T_{\text {out }}$ & $T_{\text {amb }}$ & & \\
\hline 0 & 0 & & & & & & & \\
\hline 20 & 0.1 & 0.3 & 37.2 & 32.6 & 73.5 & 73 & 10.97 & 1.10 \\
\hline 28 & 0.44 & 1.5 & 31 & 30 & 71 & 73 & 2.31 & -4.38 \\
\hline 36 & 1.05 & 3.6 & 31.1 & 30 & 71.5 & 73 & 2.51 & -3.29 \\
\hline 44 & 2 & 6.8 & 31.9 & 31 & 71.7 & 73 & 1.88 & -2.85 \\
\hline 52 & 3 & 10.2 & 33.15 & 31.8 & 76.5 & 73 & 2.98 & 7.67 \\
\hline 60 & 4.26 & 14.5 & 34.45 & 33 & 76 & 73 & 3.28 & 6.57 \\
\hline 68 & 5.95 & 20.3 & 35.85 & 34 & 81.8 & 73 & 3.91 & 19.27 \\
\hline 76 & 8 & 27.3 & 37.6 & 36.2 & 86.7 & 73 & 3.05 & 30.00 \\
\hline
\end{tabular}


In Table 5, initially, the heat loss to the box from the room across the window is very high and it falls as time passes, before stabilizing after $30 \mathrm{~min}$. This is primarily because the window has a heat capacity, which is higher than the surrounding air. So, it takes some time to cool down and stabilize.

The heat output rate, as shown in

Table 6, to outside of the box is a negative number in some cases. The negative number implies that the heating rate due to the power input is not sufficient for dominating the cooling effect caused by the ice inside the box, and the fan blowing the cold air over the window. Therefore, heat from the room is still being lost to the box. As the power input to the window is raised the heating rate eventually overtakes the cooling rate, and the window pane facing the room starts heating up beyond the room temperature. The calculated heat output for some situations is higher than the actual heat input. This may be explained by the influence of several factors. The heat loss is calculated based on an average velocity. It was however observed that the velocity of air across the face of the window varied vastly. Therefore, the calculated heat output may be overestimated. Also, the window itself was observed to have a temperature gradient, where it was at its hottest at the center and slightly cooler close to the corners. Due to the limited availability of thermocouples, the window temperatures were measures at limited number of locations. The temperature estimation can be improved by using more thermocouples to measure the temperature gradient across the face of the window. The box was cooled using ice packs and a small desk fan placed inside the box, due to limited resources. If the box were to be cooled using a refrigeration system and a better and wider fan used for blowing 
air over the window, the velocity and temperature gradients across the window due to cooling would be far reduced and the calculated heat output would be far closer to actual heat output from the window.

Given the high variability in the data across various tests, over a range of temperatures, the percentage error in the outputs was plotted against the power input. This is shown in Figure 14. It can be seen that the error was the lowest, whenever the heated side was at about the room temperature. Based on this observation, it is safe to say that the maintaining the heated window pane facing the room, close to room temperature will minimize the error in the data, and the heat output to the cold box at this temperature is reliable. The heated pane temperature, as well as the ambient temperature for each of the cases is shown in Table 7.

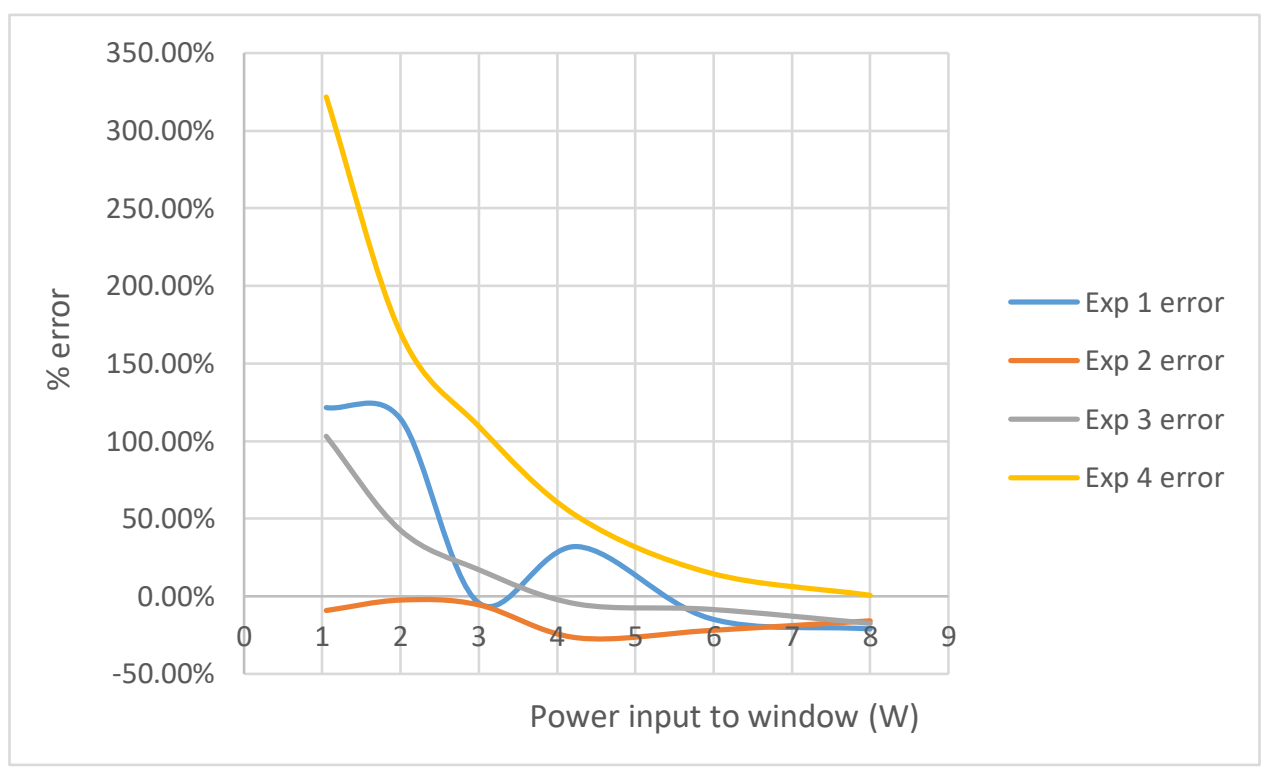

Figure 14 Error in heat output calculated vs power input

In Table 7, the window temperatures closest to the room temperature have been highlighted. It can be seen that the variation of the data increases as we move away from 
a window temperature close to the ambient temperature, except in the case of experiment 4. The higher error in experiment 4 may be due to errors brought about by increasing room temperature. With better equipment to measure the temperature at multiple points across the face of the window, as well as a better measure of the overall velocity across the window, these errors may be reduced.

Table 7 Power input and the respective window temp for different experiments

\begin{tabular}{|l|l|l|l|l|l|l|l|l|}
\hline \multirow{2}{*}{$\begin{array}{l}\text { Power } \\
\text { Input } \\
(\mathbf{W})\end{array}$} & \multicolumn{2}{|l|}{ Experiment 1 } & \multicolumn{2}{l|}{ Experiment 2 } & \multicolumn{2}{l|}{ Experiment 3 } & \multicolumn{2}{l|}{ Experiment 4 } \\
\cline { 2 - 9 } & $\begin{array}{l}\text { Window } \\
\text { Temp. } \\
\left({ }^{\circ} \mathbf{F}\right)\end{array}$ & $\begin{array}{l}\text { Ambient } \\
\text { Temp. } \\
\left({ }^{\circ} \mathbf{F}\right)\end{array}$ & $\begin{array}{l}\text { Window } \\
\text { Temp. } \\
\left({ }^{\circ} \mathbf{F}\right)\end{array}$ & $\begin{array}{l}\text { Ambient } \\
\text { Temp. } \\
\left({ }^{\circ} \mathbf{F}\right)\end{array}$ & $\begin{array}{l}\text { Window } \\
\text { Temp. } \\
\left({ }^{\circ} \mathbf{F}\right)\end{array}$ & $\begin{array}{l}\text { Ambient } \\
\text { Temp. } \\
\left({ }^{\circ} \mathbf{F}\right)\end{array}$ & $\begin{array}{l}\text { Window } \\
\text { Temp. } \\
\left({ }^{\circ} \mathbf{F}\right)\end{array}$ & $\begin{array}{l}\text { Ambient } \\
\text { Temp. } \\
\left({ }^{\circ} \mathbf{F}\right)\end{array}$ \\
\hline 1.05 & 71.5 & 73 & 74.8 & 75.4 & 75.1 & 76.4 & 72.7 & 79 \\
\hline 2 & 71.7 & 73 & 76.2 & 75.4 & 76.9 & 76.4 & 74.6 & 79 \\
\hline 3 & 76.5 & 73 & 78.2 & 75.4 & 78.8 & 76.4 & 77.3 & 79 \\
\hline 4.26 & 76 & 73 & 81 & 75.4 & 81.8 & 76.4 & 80.2 & 79 \\
\hline 5.95 & 81.8 & 73 & 84.2 & 75.4 & 84.9 & 76.4 & 84.6 & 79 \\
\hline 8 & 86.7 & 73 & 87.7 & 75.4 & 89.3 & 76.4 & 89.1 & 79 \\
\hline
\end{tabular}

The heat output (loss) inside the box, as show in Figure 15 for experiment 1, when the window is heated and not heated vs time. As shown in Figure 15, the heat loss from the heated window to the cold outside, represented by the inside of the box, is about half of what it is for a non-heated window. It must be noted that only one case is considered here since the ambient temperature for both the heated, and the unheated windows were close to each other, around $73^{\circ} \mathrm{F}$. In all other cases, the temperature difference was more than $1^{\circ} \mathrm{F}$. An interesting thing to note here is that the heat loss through the window is at its lowest between 40 to 50 min. This is the same time range when the face of the window facing the warm room is hot enough to match the room temperature. As the temperature 
of the window is raised beyond the room temperature, the heat loss through the window starts increasing again. This indicates that the heated window may be effective when used within a certain temperature range, which coordinates closely with the room temperature. In general, the heat loss through the heated window, vs a non-heated window, is reduced by as much as $50 \%$ per unit window area. The total heat loss reduction from the heating system, however, might be small fraction of the total heat put out by the furnace.

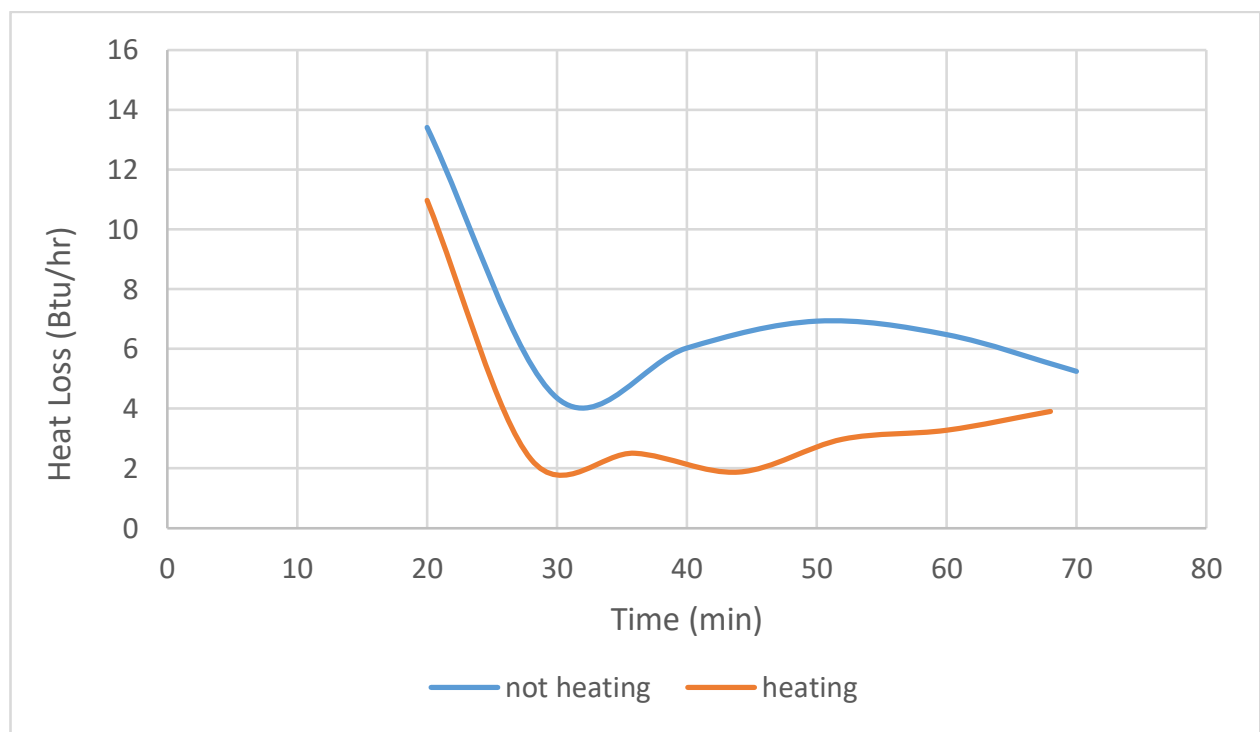

Figure 15 Comparison of heat loss for heated vs unheated window

To check the effects of window temperature higher than room temperature, tests were performed by increasing the power input to the window further so that the window temperature went above room temperature. Table 7 shows the results of those tests. Figure 16 shows the relationship between heat loss through the window to outside, vs the heated window temperature. 
Table 8 Heat loss through the heated double pane window at higher heat input

\begin{tabular}{|c|c|c|c|c|c|c|c|c|}
\hline \multirow{3}{*}{$\begin{array}{l}\text { Time } \\
(\min )\end{array}$} & \multirow{3}{*}{$\begin{array}{c}\text { Power Input } \\
\text { (Watts) }\end{array}$} & \multirow{3}{*}{$\begin{array}{l}\text { Power Input } \\
\text { (btu/h) }\end{array}$} & \multicolumn{4}{|c|}{ Temperature $\left({ }^{\circ} \mathrm{F}\right)$} & \multicolumn{2}{|c|}{$\begin{array}{l}\text { Heat Output Rate } \\
\text { (btu/h) }\end{array}$} \\
\hline & & & Window & $\begin{array}{c}\text { Inside } \\
\text { Box }\end{array}$ & Window & Ambient & Inside & Outside \\
\hline & & & $T_{\text {in }}$ & $T_{\text {box }}$ & $T_{\text {out }}$ & $T_{a m b}$ & & \\
\hline 0 & 0 & & & & & & & \\
\hline 50 & 3 & 10.23 & 30 & 26 & 70 & 70 & 6.93 & 0.45 \\
\hline 80 & 7 & 23.87 & 31 & 28 & 76 & 70 & 7.04 & 12.40 \\
\hline 100 & 12 & 40.92 & 34 & 30 & 84 & 70 & 8.15 & 31.63 \\
\hline 120 & 20 & 68.20 & 36 & 32 & 96 & 70 & 10.39 & 57.10 \\
\hline 160 & 28 & 95.48 & 42 & 35 & 112 & 70 & 16.76 & 93.98 \\
\hline
\end{tabular}

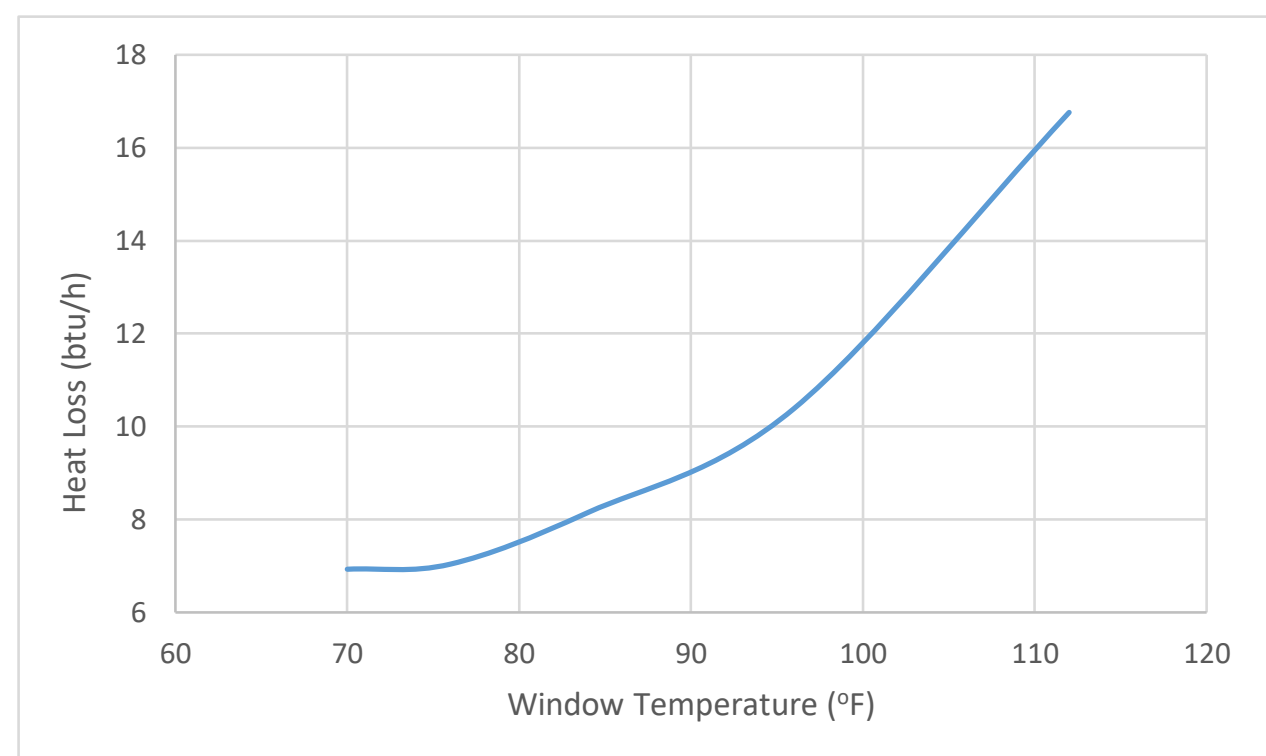

Figure 16 Relationship between window temperature and heat loss

From the data in Figure 16, we can see that the heat loss through the window is constant and at its minimum value, when the window is maintained close to room temperature $\left(73^{\circ} \mathrm{F}\right)$. Heat loss is higher when the temperature of the window is increased beyond the room temperature. It must be noted that in Table $\mathbf{8}$, the box temperature is increasing with increasing heat input or increasing window temperature. This illustrates a big 
drawback of the current setup. Given the limited amount of ice packs added to the box, the box is not able to sustain a fairly constant temperature with increasing window temperature. This can create artifacts in the data, like underestimating the actual heat loss through the window.

The calculations are based on the following conditions:

Length of heating season: 7 months/year

From Figure 15, Heat loss reduction per unit area through heated window vs non-heated window: $50 \%$

Average box temperature: $32^{\circ} \mathrm{F}$

Average room temperature: $73^{\circ} \mathrm{F}$

Window Area: $1.5 \mathrm{ft}^{2}$

Heat loss through $1.5 \mathrm{ft}^{2}$ heated window maintained at $73^{\circ} \mathrm{F}$ from Table 6: $2 \mathrm{Btu} / \mathrm{hr}$ Heat loss per $\mathrm{ft}^{2}$ for heated window $\left(\mathrm{Q}_{\mathrm{H}}\right): 1.33 \mathrm{Btu} / \mathrm{hr}^{-\mathrm{ft}^{2}}$

Heat loss through $1.5 \mathrm{ft}^{2}$ un-heated window from Table 5: $4.36 \mathrm{Btu} / \mathrm{hr}$

Heat loss per $\mathrm{ft}^{2}$ for un-heated window (QuH): $2.91 \mathrm{Btu} / \mathrm{hr}^{-\mathrm{ft}^{2}}$

Therefore, the total energy savings for the whole heating season may be calculated as follows:

Energy savings using heated window, $E S=Q_{H}-Q_{H}$

$$
\begin{aligned}
E S & =2.91 B t u / h r-f t^{2}-1.33 B t u / h r-f t^{2} \\
& =1.58 B t u / h r-f t^{2}
\end{aligned}
$$

Number of hrs in a 7-month heating season, $\mathrm{T}=8,760 \mathrm{hrs} / \mathrm{yr} \times \mathrm{7/12}$

Therefore, $\quad \mathrm{T}=5,110 \mathrm{hrs} / \mathrm{yr}$ 
Total Energy savings for a heating season TES $=\mathrm{ES} \times \mathrm{T}$

$$
\begin{aligned}
\text { TES } & =1.58 \mathrm{Btu} / \mathrm{hr}-\mathrm{ft}^{2} \times 5,110 \mathrm{hrs} / \mathrm{yr} \\
& =8,074 \mathrm{Btu} / \mathrm{yr}-\mathrm{ft}^{2}
\end{aligned}
$$

The average cost of Natural Gas and Electrical Costs for residential sector for Morgantown, WV are shown in Table 9.

Table 9 Cost of Electricity and Natural Gas for Residential Customer in Morgantown, WV in 2017.

\begin{tabular}{|c|c|}
\hline Resource & Cost \\
\hline Electricity & $\$ 0.102 / \mathrm{kWh}$ \\
\hline Natural Gas & $\$ 9.57 / \mathrm{MCF}$ \\
\hline
\end{tabular}

Therefore, energy cost savings, ECSE, in the case of using an electrical heating system (99\% efficient) over the 7-month heating season may be calculated as follows

$$
\begin{aligned}
\text { ECS }_{E} & =\text { TES Btu/yr-ft }{ }^{2} \times 0.000293 \mathrm{kWh} / \text { Btu } \times \$ 0.102 / \mathrm{kWh} \times(1 / 0.99) \\
& =8,074 \mathrm{Btu} / \mathrm{yr}-\mathrm{ft} \mathrm{t}^{2} \times 0.000293 \mathrm{kWh} / \text { Btu } \times \$ 0.102 / \mathrm{kWh} \times(1 / 0.99) \\
& =\$ 0.24 / y r-f t^{2}
\end{aligned}
$$

Similarly, energy cost savings, ECS $N$, in the case of using a natural gas forced air heating system ( $90 \%$ efficient) over the 7-month heating season may be calculated as follows

ECS $_{N G}=$ TES Btu/yr-ft $\times(1 / 1,000,000) M C F / B t u \times \$ 9.57 / M C F \times$ 
$\mathrm{ECS}_{\mathrm{NG}}=8,074 \mathrm{Btu} / \mathrm{yr}-\mathrm{ft}^{2} \times(1 / 1,000,000) \mathrm{MCF} / \mathrm{Btu} \times \$ 9.57 / \mathrm{MCF} \times$

$$
=\$ 0.09 / \mathrm{yr}-\mathrm{ft}^{2}
$$

For a house with 5 windows each of $9 \mathrm{ft}^{2}$ area, the proportional cost savings are shown in Table 10.

Table 10 Cost savings by installing a heated window.

\begin{tabular}{|c|c|c|}
\hline Resource & $\begin{array}{l}\text { Cost Savings for window } \\
\qquad\left(\$ / y r-\mathrm{ft}^{2}\right)\end{array}$ & $\begin{array}{l}\text { Cost Savings for five } \\
9 \mathrm{ft}^{2} \text { windows }\left(\$ / y r-\mathrm{ft}^{2}\right)\end{array}$ \\
\hline Electricity & $\$ 0.24 / y r-f t^{2}$ & $\$ 10.80 / \mathrm{yr}$ \\
\hline Natural Gas & $\$ 0.09 / y r-f t^{2}$ & $\$ 4.05 / y r$ \\
\hline
\end{tabular}

Therefore, for the case where the outside temperature is $32^{\circ} \mathrm{F}$ average over a 7 -month heating season, and the house within Morgantown, WV, with 5 windows each of $9 \mathrm{ft}^{2}$ maintained at $73^{\circ} \mathrm{F}$ throughout the day would save $\$ 10.80$ if the house uses an electrical resistance heating system, or $\$ 4.05$, if it uses natural gas based forced air heating system.

\subsection{R-Value of Heated Window}

The R-value is a measure of thermal resistance, or ability of heat to transfer from hot to cold, through materials or assemblies of materials. The R-value of the heated window may be estimated for the cases when the heated window temperature is close to room temperature. R-value may be defined as follows: 


$$
\mathrm{R}=(\mathrm{A} \cdot \Delta \mathrm{T}) /(\mathrm{Q})
$$

Where,

$\mathrm{R}=$ thermal resistivity of the window, ${ }^{\circ} \mathrm{F}-\mathrm{ft}^{2}-\mathrm{hr} / \mathrm{Btu}$

$\mathrm{Q}=$ Heat loss through the window, Btu/hr

$\Delta \mathrm{X}=$ Thickness of the window, $1 / 12 \mathrm{ft}$

A $=$ Area of the window face, $1.5 \mathrm{ft}^{2}$

$\Delta \mathrm{T}=$ Temperature difference across the two faces of the window.

Table 11 shows the various parameters in 4 different experiments, when the window was heated close to the room temperature, while the box was being cooled. For these cases, the head loss through the window was found to be minimum. The equivalent R-values for each of the cases is also noted.

\begin{tabular}{|c|c|c|c|c|c|c|}
\hline \multirow{2}{*}{ Experiment } & \multicolumn{4}{|c|}{ Temperature ( ${ }^{\circ}$ F) } & $\begin{array}{c}\text { Heat Output Rate } \\
\text { (btu/h) }\end{array}$ & R-value \\
\cline { 2 - 7 } & $\begin{array}{c}\text { Inside } \\
\text { Pane }\end{array}$ & $\begin{array}{c}\text { Inside } \\
\text { Box }\end{array}$ & $\begin{array}{c}\text { Outside } \\
\text { Pane }\end{array}$ & Ambient & Inside Box & \multirow{2}{*}{${ }^{\circ}$ F-ft ${ }^{2}$-hr/Btu } \\
\cline { 2 - 5 } & $T_{\text {in }}$ & $T_{\text {box }}$ & $T_{\text {out }}$ & $T_{\text {amb }}$ & & \\
\hline 1 & 32 & 31 & 71.7 & 73 & 1.88 & 380.106 \\
\hline 2 & 37 & 35.2 & 74.8 & 75.4 & 5.24 & 129.847 \\
\hline 3 & 41 & 40.4 & 76.9 & 76.4 & 2.81 & 229.964 \\
\hline 4 & 39.6 & 38.2 & 80.2 & 79 & 4.42 & 165.339 \\
\hline
\end{tabular}

\subsection{Conclusion}

The effectiveness of a heated double-pane window vs a standard double-pane window, was tested. A temperature gradient was developed across the window by installing it on 
an insulated box and placing ice packs inside the box. The temperature of the room, box, and inside and outside panes of the window were recorded. The following conclusions were drawn:

1. The heated double pane window appears to show benefits over an un-heated counterpart provided that the window pane, facing the room, is maintained close to the room temperature.

a. The energy loss through the window increases significantly when the window temperature is much higher than room temperature.

2. Conduction is the dominant mode of heat propagation. This ensures that most the heat from the heated window goes into the room.

3. The heat loss through per $\mathrm{ft}^{2}$ heated window vs an unheated window appears to reduce by as much as $50 \%$ when the window is heated to temperature of the room.

4. For a case study of a 7-month heating season in Morgantown, WV, comparing a heated window vs a non-heated window, the electrical cost savings using a heated window is $\$ 0.24 / y r-f t^{2}$, and the natural gas cost savings are $\$ 0.09 / y r-f t^{2}$. It is therefore concluded that there are no savings using a heated window, vs a unheated window.

\subsection{Future Work}

Given the limitations of the experimental setup, especially with reaching the equilibrium conditions, it is hard to predict the performance of the window when the power input is low. 
Some of the issues encountered while preparing the experimental setup and recommendations for future research are as follows:

- For cooling the box, gel based ice packs were used, for the sake of simplicity and keeping the cost of the setup reasonable

- A refrigeration system that is sized for the box with proper control on the temperature would greatly improve the reliability of the data

- The ice-packs were arranged in a similar manner in all the tests. However, there was some variation in the arrangement, which caused some level of variation in the cooling within the box, or the air flow. The use of a refrigeration system to cool the box would have mitigated this issue and given much more consistent air-flow patterns within the box.

- While similar types of thermocouples were used for this project, the number of points where the temperature data could be collected was just 4 . During the testing phase, it was realized that there was a temperature gradient across the face of the window. Also, the velocity of the air was not constant across the face of the window. Effort was made to minimize the errors by calculating the average velocity over multiple experiments, and using that in all experiments, apart from fixing the fan position within the box. A refrigeration system with forced air cooling, where the fan speed could be modulated would be ideal for reducing the gradients in the velocity across the face of the window and the errors it may bring while calculating heat loss. 
- For better control over the window performance, it should have a controller and feedback system built in, so it may be connected to the thermostat of the building.

- Studies may be facilitated to be performed at the residential and commercial building test beds at ORNL (Oak Ridge National Lab) 


\section{Bibliography}

[1] Doe/Eia, "US Energy Consumption by Sector," 2015.

[2] Doe/Eia, "How much energy is consumed in residential and commercial buildings in the United States?," 2016.

[3] Doe/Eia, "US Residential Energy Consumption by End Use," 2009.

[4] Doe/Eia, "Tips: Windows."

[5] NFRC, "Benefits of Improving Windows," 2012.

[6] Doe/Eia, "US Annual Electric Power Consumption by sector," 2016.

[7] US - Department of Labor and Statistics, "The effects of shale gas production on natural gas prices," 2013.

[8] T. Hodge, "Growth in residential electricity prices highest in 6 years, but expected to slow in 2015," US Energy Information Administration, 2015.

[9] Center for Climate and Energy Solutions, "Building Envelope," Climate Techbook, pp. 1-7, Apr. 2011.

[10] S. Hayes, N. Baum, and G. Herndon, "Energy Efficiency : Is the United States Improving ?," American Council of Energy Efficient Economy, Jul. 2013. 
[11] C. Regnier, "Guide to Setting Thermal Comfort Criteria and Minimizing Energy Use in Delivering Thermal Comfort." Ernest Orlando Lawrence Berkeley National Laboratory, Aug-2012.

[12] M. D. Freestone, "Radient and Perimeter Heating Options: Effectiveness and Thermal Comfort," ASHRAE Transactions, vol. 102, no. 1, pp. 667-675, 1996.

[13] P. R. Lyons, D. Arasteh, and C. Huizenga, "Window performance for human thermal comfort," Transactions - American Society of Heating, Refrigerating and Air Conditioning Engineers, vol. 106, pp. 594-604, Aug. 1999.

[14] J. A. Myhren and S. Holmberg, "Flow patterns and thermal comfort in a room with panel, floor and wall heating," Energy and Buildings, vol. 40, no. 4, pp. 524-536, Jan. 2008.

[15] X. Gong and D. E. Claridge, "Impact of the position of the radiators on energy consumption and thermal comfort in a mixed radiant and convective heating system," ASHRAE Transactions, vol. 113 PART 1, pp. 494-503, 2007.

[16] R. Gao, A. Li, O. Zhang, and H. Zhang, "Comparison of indoor air temperatures of different under-floor heating pipe layouts," Energy Conversion and Management, vol. 52, no. 2, pp. 1295-1304, Feb. 2011.

[17] P. Waide, "Energy Efficiency in the North American Existing Building Stock," US Energy Information Administration, p. 112, Jul. 2007.

[18] US Department of Energy, "Quadrennial Technology Review: An Assessment of 
Energy Technologies and Research Chapter 5: Increasing Efficiency of Building Systems and Technologies," Sep. 2015.

[19] D. Arasteh, "Advances in window technology: 1973-1993," in Advances in solar energy, an annual review of research and development, vol. 9, 1994, pp. 339382.

[20] S. B. Sadineni, S. Madala, and R. F. Boehm, "Passive building energy savings: A review of building envelope components," Renewable and Sustainable Energy Reviews, vol. 15, no. 8, pp. 3617-3631, Oct. 2011.

[21] M. Hutchins and W. Platzer, "The thermal performance of advanced glazing materials," Renewable Energy, vol. 8, no. 1-4, pp. 540-545, May 1996.

[22] A. Moreau, M. A. Sc, S. Sansregret, E. M. A. Sc, M. Fournier, and M. A. Sc, "Modeling and Study of the Impacts of Electrically Heated Windows on the Energy Needs of Buildings," in International Conference on HEAT TRANSFER, THERMAL ENGINEERING and ENVIRONMENT (HTE'08), 2008, pp. 76-83.

[23] D. Bastien and A. K. Athienitis, "Methodology for selecting fenestration systems in heating dominated climates," Applied Energy, vol. 154, pp. 1004-1019, Sep. 2015.

[24] J. S. Apte and D. K. Arasteh, "Window-Related Energy Consumption in the US Residential and Commercial Building Stock, Lawrence Berkeley National Laboratory report, LBNL-60146," 2006. 
[25] D. B. Özkan and C. Onan, "Optimization of insulation thickness for different glazing areas in buildings for various climatic regions in Turkey," Applied Energy, vol. 88, no. 4, pp. 1331-1342, Apr. 2011.

[26] H. Manz and U.-P. Menti, "Energy performance of glazings in European climates," Renewable Energy, vol. 37, no. 1, pp. 226-232, Jan. 2012.

[27] T. C. Lam, H. Ge, and P. Fazio, "Impact of Curtain Wall Configurations on Building Energy Performance in the Perimeter Zone for a Cold Climate," Energy Procedia, vol. 78, pp. 352-357, Nov. 2015.

[28] A. Gustavsen, S. Grynning, D. Arasteh, B. P. Jelle, and H. Goudey, "Key elements of and material performance targets for highly insulating window frames," Energy and Buildings, vol. 43, no. 10, pp. 2583-2594, Oct. 2011.

[29] D. Arasteh, S. Selkowitz, J. Apte, and M. LaFrance, "Zero Energy Windows," in Proceedings of the 2006 ACEEE Summer Study on Energy Efficiency in Buildings, 2006, pp. 1-14.

[30] B. P. Jelle, A. Hynd, A. Gustavsen, D. Arasteh, H. Goudey, and R. Hart, "Fenestration of today and tomorrow: A state-of-the-art review and future research opportunities," Solar Energy Materials and Solar Cells, vol. 96, pp. 1-28, Jan. 2012.

[31] J. Kurnitski, J. Jokisalo, J. Palonen, K. Jokiranta, and O. Seppänen, "Efficiency of electrically heated windows," Energy and Buildings, vol. 36, no. 10 SPEC. ISS., 
pp. 1003-1010, 2004.

[32] E. M. Ryan and T. F. Sanquist, "Validation of building energy modeling tools under idealized and realistic conditions," Energy and Buildings, vol. 47, pp. 375382, Apr. 2012.

[33] E. H. Borgstein, R. Lamberts, and J. L. M. Hensen, "Evaluating energy performance in non-domestic buildings: A review," Energy and Buildings, vol. 128, pp. 734-755, Sep. 2016.

[34] J. Virote and R. Neves-Silva, "Stochastic models for building energy prediction based on occupant behavior assessment," Energy and Buildings, vol. 53, pp. 183-193, Oct. 2012.

[35] H. Zhao and F. Magoulès, "A review on the prediction of building energy consumption," Renewable and Sustainable Energy Reviews, vol. 16, no. 6, pp. 3586-3592, Aug. 2012.

[36] L. La Fleur, B. Moshfegh, and P. Rohdin, "Measured and predicted energy use and indoor climate before and after a major renovation of an apartment building in Sweden," Energy and Buildings, vol. 146, pp. 98-110, 2017.

[37] L. Pérez-Lombard, J. Ortiz, J. F. Coronel, and I. R. Maestre, "A review of HVAC systems requirements in building energy regulations," Energy and Buildings, vol. 43, no. 2-3, pp. 255-268, Feb. 2011.

[38] Y. Yaşar and S. M. Kalfa, "The effects of window alternatives on energy efficiency 
and building economy in high-rise residential buildings in moderate to humid climates," Energy Conversion and Management, vol. 64, pp. 170-181, Dec. 2012.

[39] M. Bojic, F. Yik, and P. Sat, "Energy performance of windows in high-rise residential buildings in Hong Kong," Energy and Buildings, vol. 34, no. 1, pp. 7182, Jan. 2002.

[40] S. Yoo, H. Jeong, B.-L. Ahn, H. Han, D. Seo, J. Lee, and C.-Y. Jang, "Thermal transmittance of window systems and effects on building heating energy use and energy efficiency ratings in South Korea," Energy and Buildings, vol. 67, pp. 236244, Dec. 2013.

[41] K. Tsikaloudaki, T. Theodosiou, K. Laskos, and D. Bikas, "Assessing cooling energy performance of windows for residential buildings in the Mediterranean zone," Energy Conversion and Management, vol. 64, pp. 335-343, Dec. 2012.

[42] K. Hassouneh, A. Alshboul, and A. Al-Salaymeh, "Influence of windows on the energy balance of apartment buildings in Amman," Energy Conversion and Management, vol. 51, no. 8, pp. 1583-1591, Aug. 2010.

[43] M. Maerefat, A. Zolfaghari, and A. Omidvar, "On the conformity of floor heating systems with sleeping in the eastern-style beds; physiological responses and thermal comfort assessment," Building and Environment, vol. 47, pp. 322-329, Jan. 2012.

[44] J. Ren, L. Zhu, Y. Wang, C. Wang, and W. Xiong, "Very low temperature radiant 
heating/cooling indoor end system for efficient use of renewable energies," Solar Energy, vol. 84, no. 6, pp. 1072-1083, Jun. 2010.

[45] F. Causone, F. Baldin, B. W. Olesen, and S. P. Corgnati, "Floor heating and cooling combined with displacement ventilation: Possibilities and limitations," Energy and Buildings, vol. 42, no. 12, pp. 2338-2352, Dec. 2010.

[46] X. Q. Zhai, R. Z. Wang, Y. J. Dai, J. Y. Wu, Y. X. Xu, and Q. Ma, "Solar integrated energy system for a green building," Energy and Buildings, vol. 39, no. 8, pp. 985-993, Aug. 2007.

[47] L. Fontana, "Thermal performance of radiant heating floors in furnished enclosed spaces," Applied Thermal Engineering, vol. 31, no. 10, pp. 1547-1555, Jul. 2011.

[48] S. Sattari and B. Farhanieh, "A parametric study on radiant floor heating system performance," Renewable Energy, vol. 31, no. 10, pp. 1617-1626, Aug. 2006.

[49] H. Karabay, M. Arıcı, and M. Sandık, "A numerical investigation of fluid flow and heat transfer inside a room for floor heating and wall heating systems," Energy and Buildings, vol. 67, pp. 471-478, Dec. 2013.

[50] Q. Wang, A. Ploskić, and S. Holmberg, "Retrofitting with low-temperature heating to achieve energy-demand savings and thermal comfort," Energy and Buildings, vol. 109, pp. 217-229, Dec. 2015.

[51] A. Ploskić and S. Holmberg, "Low-temperature baseboard heaters with integrated air supply - An analytical and numerical investigation," Building and Environment, 
vol. 46, no. 1, pp. 176-186, Jan. 2011.

[52] E. A. Ollokiegi, "Electric Heated Windows - Thermal Comfort and Energy Use Aspects - Masters Thesis," University of Gavle, 2013.

[53] A. American Society of Heating, Refrigerating and Air-Conditioning Engineers, ASHRAE Handbook: Fundamentals. ASHRAE, 2013. 


\section{Appendix}

Heated Window Experiment Data - \#1

\begin{tabular}{|c|c|c|c|c|c|c|c|}
\hline \multirow{3}{*}{$\begin{array}{c}\text { Cumulative } \\
\text { Time (min) } \\
0 \text { (Start) }\end{array}$} & \multirow{3}{*}{ 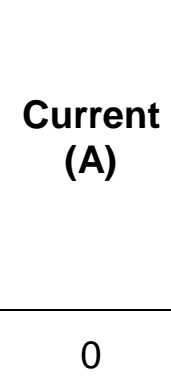 } & \multirow{3}{*}{$\begin{array}{c}\begin{array}{c}\text { Voltage } \\
\text { (V) }\end{array} \\
0\end{array}$} & \multicolumn{5}{|c|}{ Temperature } \\
\hline & & & \multicolumn{2}{|c|}{ Inside Pane $\left(T_{1}\right)$} & \multirow{2}{*}{$\begin{array}{c}\begin{array}{c}\text { Outside } \\
\text { Pane } \\
\left(\mathrm{T}_{2}\right)\end{array} \\
74\end{array}$} & \multirow{2}{*}{$\begin{array}{c}\mathbf{T}_{\text {box }} \\
74\end{array}$} & \multirow{2}{*}{$\begin{array}{r}T_{\text {amt }} \\
73\end{array}$} \\
\hline & & & 74 & 74 & & & \\
\hline 20 & 0.1 & 1 & 36.4 & 38 & 73.5 & 32.6 & 73 \\
\hline 28 & 0.2 & 2.3 & 30 & 32 & 71 & 30 & 73 \\
\hline 36 & 0.3 & 3.5 & 30.1 & 32.1 & 71.5 & 30 & 73 \\
\hline 44 & 0.4 & 5 & 31.1 & 32.7 & 71.7 & 31 & 73 \\
\hline 52 & 0.5 & 6 & 32.3 & 34 & 76.5 & 31.8 & 73 \\
\hline 60 & 0.6 & 7.1 & 33.7 & 35.2 & 76 & 33 & 73 \\
\hline 68 & 0.7 & 8.5 & 35.1 & 36.6 & 81.8 & 34 & 73 \\
\hline 76 & 0.8 & 10 & 36.9 & 38.3 & 86.7 & 36.2 & 73 \\
\hline
\end{tabular}


Heated Window Experiment Data - \#2

\begin{tabular}{|c|c|c|c|c|c|c|c|}
\hline \multirow{3}{*}{$\begin{array}{l}\text { Cumulative } \\
\text { Time (min) } \\
0 \text { (Start) }\end{array}$} & \multirow{3}{*}{$\begin{array}{c}\text { Current } \\
\text { (A) } \\
0\end{array}$} & \multirow{3}{*}{$\begin{array}{c}\begin{array}{c}\text { Voltage } \\
\text { (V) }\end{array} \\
0\end{array}$} & \multicolumn{5}{|c|}{ Temperature } \\
\hline & & & \multicolumn{2}{|c|}{ Inside Pane $\left(T_{1}\right)$} & \multirow{2}{*}{$\begin{array}{c}\begin{array}{c}\text { Outside } \\
\text { Pane } \\
\left(\mathbf{T}_{2}\right)\end{array} \\
76.3\end{array}$} & \multirow{2}{*}{$\begin{array}{l}T_{\text {box }} \\
76.4\end{array}$} & \multirow{2}{*}{\begin{tabular}{|l}
$\mathbf{T}_{\text {amb }}$ \\
75.4
\end{tabular}} \\
\hline & & & 76 & 76.3 & & & \\
\hline 20 & 0.1 & 1 & 36 & 38.7 & 74.7 & 34 & 75.4 \\
\hline 28 & 0.2 & 2.3 & 35.2 & 37.9 & 74.2 & 34.4 & 75.4 \\
\hline 36 & 0.3 & 3.5 & 35.5 & 38.3 & 74.8 & 34.6 & 75.4 \\
\hline 44 & 0.4 & 5 & 36.5 & 38.9 & 76.2 & 35.2 & 75.4 \\
\hline 52 & 0.5 & 6 & 37.3 & 39.7 & 78.2 & 36.4 & 75.4 \\
\hline 60 & 0.6 & 7.1 & 38.3 & 40.7 & 81 & 36.8 & 75.4 \\
\hline 68 & 0.7 & 8.5 & 39.4 & 41.8 & 84.2 & 38 & 75.4 \\
\hline 76 & 0.8 & 10 & 40.4 & 42.7 & 87.7 & 39.4 & 75.4 \\
\hline
\end{tabular}


Heated Window Experiment Data - \#3

\begin{tabular}{|c|c|c|c|c|c|c|c|}
\hline \multirow{3}{*}{$\begin{array}{c}\text { Cumulative } \\
\text { Time (min) } \\
0 \text { (Start) }\end{array}$} & \multirow{3}{*}{$\begin{array}{c}\begin{array}{c}\text { Current } \\
\text { (A) }\end{array} \\
0\end{array}$} & \multirow{3}{*}{$\begin{array}{c}\begin{array}{c}\text { Voltage } \\
\text { (V) }\end{array} \\
0\end{array}$} & \multicolumn{5}{|c|}{ Temperature } \\
\hline & & & \multicolumn{2}{|c|}{ Inside Pane $\left(T_{1}\right)$} & \multirow{2}{*}{$\begin{array}{c}\begin{array}{c}\text { Outside } \\
\text { Pane } \\
\left(\mathrm{T}_{2}\right)\end{array} \\
77.8\end{array}$} & \multirow{2}{*}{\begin{tabular}{|l} 
box \\
76.4
\end{tabular}} & \multirow{2}{*}{\begin{tabular}{|l}
$\mathbf{T}_{\mathrm{amb}}$ \\
76.4
\end{tabular}} \\
\hline & & & 76.5 & 76.7 & & & \\
\hline 20 & 0.1 & 1 & 38.2 & 40.2 & 73.9 & 37.4 & 76.4 \\
\hline 28 & 0.2 & 2.3 & 38.6 & 40.4 & 74.1 & 38 & 76.4 \\
\hline 36 & 0.3 & 3.5 & 39.3 & 40.9 & 75.1 & 38.9 & 76.4 \\
\hline 44 & 0.4 & 5 & 40.1 & 41.8 & 76.9 & 39.6 & 76.4 \\
\hline 52 & 0.5 & 6 & 41.1 & 42.6 & 78.8 & 40.4 & 76.4 \\
\hline 60 & 0.6 & 7.1 & 42.1 & 43.5 & 81.8 & 41.3 & 76.4 \\
\hline 68 & 0.7 & 8.5 & 43 & 44.4 & 84.9 & 42.1 & 76.4 \\
\hline 76 & 0.8 & 10 & 43.8 & 45.3 & 89.3 & 42.8 & 76.4 \\
\hline
\end{tabular}


Heated Window Experiment Data - \#4

\begin{tabular}{|c|c|c|c|c|c|c|c|}
\hline \multirow{3}{*}{$\begin{array}{l}\text { Cumulative } \\
\text { Time (min) } \\
0 \text { (Start) }\end{array}$} & \multirow{3}{*}{$\begin{array}{c}\text { Current } \\
\text { (A) } \\
0\end{array}$} & \multirow{3}{*}{$\begin{array}{c}\begin{array}{c}\text { Voltage } \\
\text { (V) }\end{array} \\
0\end{array}$} & \multicolumn{5}{|c|}{ Temperature } \\
\hline & & & \multicolumn{2}{|c|}{ Inside Pane $\left(T_{1}\right)$} & \multirow{2}{*}{$\begin{array}{c}\begin{array}{c}\text { Outside } \\
\text { Pane } \\
\left(\mathrm{T}_{2}\right)\end{array} \\
78\end{array}$} & \multirow{2}{*}{$\begin{array}{l}\mathrm{T}_{\text {box }} \\
33\end{array}$} & \multirow{2}{*}{$\begin{array}{r}\mathbf{T}_{\mathrm{amb}} \\
79\end{array}$} \\
\hline & & & 78 & 78 & & & \\
\hline 20 & 0.1 & 1 & 34.5 & 36.8 & 71.9 & 32.4 & 79 \\
\hline 28 & 0.2 & 2.3 & 34.8 & 37 & 71.7 & 32.9 & 79 \\
\hline 36 & 0.3 & 3.5 & 35.6 & 37.5 & 72.7 & 34 & 79 \\
\hline 44 & 0.4 & 5 & 36.8 & 38.5 & 74.6 & 35.3 & 79 \\
\hline 52 & 0.5 & 6 & 37.8 & 39.5 & 77.3 & 37.4 & 79 \\
\hline 60 & 0.6 & 7.1 & 38.9 & 40.2 & 80.2 & 37.6 & 79 \\
\hline 68 & 0.7 & 8.5 & 39.8 & 41.3 & 84.6 & 38.2 & 79 \\
\hline 76 & 0.8 & 10 & 40.9 & 42.5 & 89.1 & 39.4 & 79 \\
\hline
\end{tabular}


Unheated Window Experiment Data

\begin{tabular}{|c|c|c|c|c|c|c|c|}
\hline \multirow{3}{*}{$\begin{array}{l}\text { Cumulative } \\
\text { Time (min) } \\
0 \text { (Start) }\end{array}$} & \multirow{3}{*}{$\begin{array}{c}\text { Current } \\
\text { (A) } \\
0\end{array}$} & \multirow{3}{*}{$\begin{array}{c}\begin{array}{c}\text { Voltage } \\
\text { (V) }\end{array} \\
0\end{array}$} & \multicolumn{5}{|c|}{ Temperature } \\
\hline & & & \multicolumn{2}{|c|}{ Inside Pane $\left(T_{1}\right)$} & \multirow{2}{*}{$\begin{array}{c}\begin{array}{c}\text { Outside } \\
\text { Pane } \\
\left(\mathrm{T}_{2}\right)\end{array} \\
73.3\end{array}$} & \multirow{2}{*}{$\begin{array}{c}T_{\text {box }} \\
72\end{array}$} & \multirow{2}{*}{$\begin{array}{c}\mathbf{T}_{\mathrm{amb}} \\
71\end{array}$} \\
\hline & & & 72 & 72 & & & \\
\hline 8 & 0 & 0 & 38.8 & 40.4 & 71.3 & 31.4 & 71 \\
\hline 16 & 0 & 0 & 32.2 & 34.7 & 68.3 & 28.8 & 71 \\
\hline 24 & 0 & 0 & 31.1 & 33.6 & 66.8 & 28.6 & 71 \\
\hline 32 & 0 & 0 & 30.9 & 33 & 65.2 & 28.6 & 71 \\
\hline 40 & 0 & 0 & 31.1 & 33.1 & 64.4 & 29.6 & 71 \\
\hline 48 & 0 & 0 & 31.8 & 33.1 & 63.8 & 30.4 & 71 \\
\hline 56 & 0 & 0 & 32.3 & 33.4 & 63.4 & 31.4 & 71 \\
\hline 64 & 0 & 0 & 72 & 72 & 73.3 & 72 & 71 \\
\hline
\end{tabular}

